\title{
Critical Analysis of International Precast Concrete Pipe Standards
}

\author{
Lui S. Wong ${ }^{1(1)}$ and Moncef L. Nehdi ${ }^{2, *}$ \\ 1 VP Engineering \& Quality, Con Cast Pipe, 299 Brock Road South, Puslinch, ON N0B 2J0, Canada; \\ lswong@concastpipe.com \\ 2 Department of Civil \& Environmental Engineering, Western University, London, ON N6A 5B9, Canada \\ * Correspondence: mnehdi@uwo.ca; Tel.: +1-(519)-661-2111 (ext. 88308)
}

Received: 18 May 2018; Accepted: 13 June 2018; Published: 22 June 2018

\begin{abstract}
Reinforced concrete pipe (RCP) standard guidelines and industry practice have rather been disconnected from the end-users' expectations. No genuine effort has so far been made to create synergy between the expertise gained and advances made around the world. With the advent of strong competition from flexible pipe products and changing end-user expectations, a critical look at the current state-of-the-art is needed. In the present paper, RCP standards from a study area representing a quarter of the world's population (Canada, United States, United Kingdom, China, Australia and New Zealand) were critically analyzed. Comparisons were made in terms of product and material requirements, structural load testing, hydrostatic performance, and durability requirements. It is shown that the RCP sector lags modern developments in concrete technology, standard code advances and materials innovations. The analysis also revealed various knowledge gaps in terms of the mechanical, hydrostatic and durability performance of RCP. Recommendations emanating from this critical analysis aim at tailoring performance-based guidelines that can better capture current market needs and user expectations.
\end{abstract}

Keywords: concrete pipe; design; standard; comparison; load test; hydrostatic test; durability; hydrogen sulfide attack; corrosion

\section{Introduction}

\subsection{Reinforced Concrete Pipe Development}

Archeological evidence shows that sewer type construction has existed for thousands of years [1]. The documented history of gravity sewer pipe using rigid materials such as concrete, clay and bricks in North America can be traced back to the late 19th century [2]. Through scientific research, engineers have continuously evolved the pipe's strength, durability, and joint performance. For instance, Marston et al. [3] were the first to develop a rational design approach for a rigid pipe. They discovered that the installation conditions influenced the load acting on the pipe. Orlander [4] and Spanglar [5] further enhanced Marston's theory by better describing the stress distribution around the pipe.

In the mid-1960s, Frank Heger studied the structural behavior of reinforced concrete pipe (RCP) under the three-edge bearing test [6]. This test is still being used today as a primary structural testing method for rigid concrete pipes. The use of welded deformed wire fabric as pipe reinforcement was also reported by Frank Heger. It enhanced crack control and offered better bonding between the concrete and reinforcing steel, resulting in a substantial reduction of the needed reinforcing steel [7]. With advancements in computational technology, finite element modeling (FEM) was used to simulate the pipe-soil interaction, which provided a better approximation of the earth pressure envelope around the pipe. In the 1970s and 1980s, Heger developed earth pressure distribution based on four 
standard installation methods. This was later published by the American Society of Civil Engineering (ASCE) [8], AASHTO LRFD [9] and the Canadian Highway Bridge Design Code [10]. Going into the new millennium, fiber-reinforced concrete pipe was investigated by the industry. Steel fiber for pipe reinforcement was adopted in European Standard BS EN 1916 [11] in 2002. The use of steel fiber as primary pipe reinforcement was first published in the US [12] in 2013, followed by using synthetic fiber-reinforced concrete pipe (FRCP) [13] in 2015. Several studies of fiber-reinforced concrete in Canada were published between 2012 and 2016 [14-17].

\subsection{Competition from Flexible Pipe Industry}

Since the commercialization of polyvinyl chloride (PVC) pipe in the 1950s, its light weight, longer lay length, chemical resistance and leak free features made a significant impact on the concrete pipe industry. Subsequent developments of other flexible pipe materials, such as corrugated steel pipe (CSP), high-density polyethylene (HDPE), polypropylene (PP), fiber glass pipe, and steel reinforced high-density polyethylene (SRHDPE) offered a multitude of options to engineers when selecting pipe materials to suit design criteria. CSP and SRHDPE can be designed to $3600 \mathrm{~mm}$ and $2400 \mathrm{~mm}$ respectively (Table 1).

Table 1. List of flexible pipe products.

\begin{tabular}{|c|c|c|c|c|c|}
\hline Pipe Materials & Size Range (mm) & Length (m) & Introduced & Joint & Source \\
\hline $\begin{array}{l}\text { Polypropylene } \\
\text { Pipe }\end{array}$ & $300-1500$ & $4-6$ & NA & 10.8 psi @ 1000 h & ADS SaniTite HP \\
\hline $\begin{array}{l}\text { Corrugated } \\
\text { Polyethylene }\end{array}$ & $100-1500$ & & 1987 & Watertight & ADS N-12WT \\
\hline \multirow{2}{*}{ HDPE } & $100-900$ & $6-10$ & 1960s [18] & Soil-tight & Armtec BOSS 1000, 2000 \\
\hline & $600-1500$ & 6 & NA & $\begin{array}{l}\text { Pressure rated at } 5 \text { psi with } 10 \\
\text { psi surge }\end{array}$ & ADS N12 Low Head \\
\hline $\begin{array}{c}\text { Steel } \\
\text { Reinforced PE }\end{array}$ & $600-2400$ & 4.2 or 6.6 & NA & $\begin{array}{l}\text { Welded joint leak free Test to } \\
15 \text { psi-3 psi load head, } \\
\text { soil-tight }\end{array}$ & Armtec DuroMax \\
\hline $\begin{array}{l}\text { Fiber Glass } \\
\text { Reinforced }\end{array}$ & $450-3150$ & $0.75-6$ & 1960s [19] & Pressure classes 0-250 psi & Hobas \\
\hline PVC & $100-1500$ & - & 1950s [20] & Pressure rated at $50 \mathrm{psi}$ & Ipex Ring Tite PVC DR35 \\
\hline $\begin{array}{l}\text { Corrugated } \\
\text { Steel Pipe }\end{array}$ & $150-3600$ & - & $1896[21]$ & Soil-tight & Armtec-HelCor \\
\hline $\mathrm{RCP}$ & $300-3600$ & 2.4 & $>100$ year $[1]$ & Watertight, test to $15 \mathrm{psi}$ & OCPA \\
\hline
\end{tabular}

The difference between flexible pipe and concrete pipe is that the flexible pipe relies on the soil as part of the structural support. Flexible materials interact with the surrounding soil under overburden load by deformation. The stiffness of the surrounding soil resulting from the level of compaction provides resistance to the deformation of the pipe. This is also known as the positive arching effect. Consequently, the installation of flexible pipe is more stringent than that for concrete pipe in terms of the geometry of the trench and compaction effort of the backfill materials. However, the common misunderstanding of the differences in installation requirements between flexible and rigid pipes often puts concrete pipe at a disadvantage.

Going into the 21st century, many flexible pipe companies introduced various innovative wall profiles to improve the pipe stiffness and reduce its deformation. With improved technology and effective marketing, the flexible pipe increased its size range significantly, reaching 2400 to $3000 \mathrm{~mm}$ in diameter. Table 1 provides a list of the flexible pipe materials currently available in the North American market, showing their advantages over rigid concrete pipe. With strong marketing, flexible pipe materials pose a real challenge for concrete pipe, despite that the durability of such pipes is yet to be proven considering that, other than PVC, these products have been on the market for less than 25 years. 


\subsection{Hydrostatic Performance Challenges}

There is a need to preserve the advantages of reinforced concrete pipe through understanding the expectations of the end user and the advent of technological advancements and innovations that can propel its performance and bridge the gap between the market needs and current standards. A pipeline is expected to resist infiltration of groundwater or soil and resist the exfiltration of the flow [22]. The pipe joint is expected to withstand movements of the pipe such as deflections without causing leakage. Profiled gaskets, O-ring gaskets or welded joints are needed where the groundwater level is above invert and infiltration cannot be tolerated, especially in sanitary applications. The term "watertightness" is commonly used by specifiers to describe this condition, but this is usually misinterpreted by the pipe manufacturers. Pipe manufacturers usually perform limited routine hydrostatic tests internally and assume that the joint performs equally to the corresponding external pressure. The watertightness of a joint is interpreted based on laboratory results from the gasket supplier. Hydrostatic pressure was quantified for instance by the Ministry of Transportation Ontario (MTO) Gravity Pipe Design Guideline [22] at 10.5-m head for RCP and 7.5-m for HDPE and PVC without leak. This quantifies the hydrostatic performance expectations and conditions of any gravity sewer, including RCP. Joint performance of RCP was mentioned in several reports and publications [22,23]. Joint failures were reported due to ground movement (e.g., soil settlement), infiltration and exfiltration caused by installation and joint sealant materials, and inadequate design and application.

\subsection{Bio-Corrosion Challenges}

Challenges of microbiologically induced precast concrete pipe corrosion (MICC) poses a significant threat to RCP used to carry sewage. Concrete corrosion due to the exposure to hydrogen sulfide in the sewerage environment was first reported by Parker [24] in 1945. Hydrogen sulfide gas induced by bacteria growth on the interface between the sewage and the pipe forms sulfuric acid. The acidic environment rich in sulfate corrodes the upper part of the concrete pipe causing peeling and reduction in wall thickness and subsequent reinforcing steel corrosion. Figure 1 exhibits a 40-year old pipe removed from its service, showing the level of the sewerage. The deterioration results in mechanical strength reduction and hence, service life reduction. Wu et al. [25] recently reported a reduction in service life from 75 and 100 years to less than 20 years for a concrete tunnel segment in Edmonton constructed in 2001. 50\% reduction in the service life of concrete truck sewers were reported in their findings indicating various deterioration due to the biogenic corrosion of concrete. In recent years, various researchers have explored developing prediction models for the concrete pipe wall reduction rate and service life span [26-28] by considering factors that influence MICC. New findings however still require implementation in concrete pipe standards so that innovative improvements can be introduced in full scale RCP production.

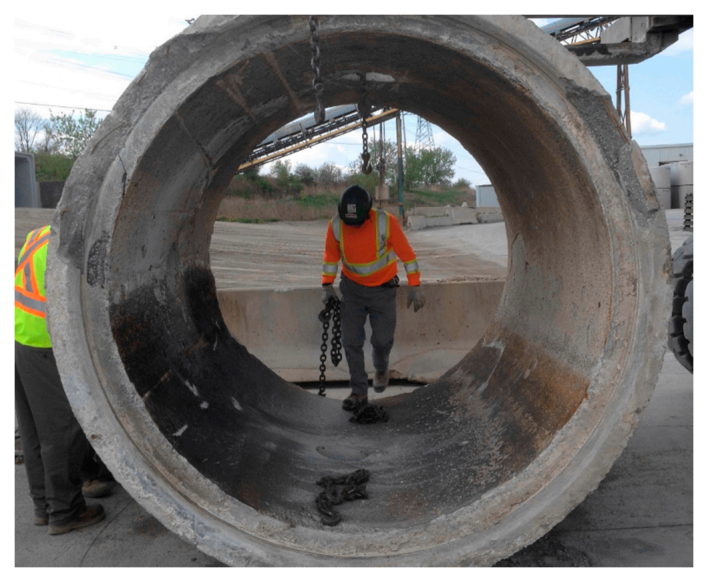

Figure 1. 40 year-old concrete pipe showing the level of sewage. 


\subsection{Scope of Study}

This paper compares the manufacturing standards of RCP used in five concrete pipe consumption countries representing a quarter of the world's population: Canada, the United States of America (US), the United Kingdom (UK), Australia and New Zealand, and the People's Republic of China (China). These countries are hereafter called the study area. The governing RCP standards in the study area are listed in Table 2. In addition to the geometry and tolerance requirements, the RCP acceptance criteria in the study area consist of structural strength, hydrostatic performance, and concrete quality. Table 3 exhibits the similarities and differences of the various acceptance criteria. This study endeavors to reveal the shortcomings of current standards and the discrepancy between them and the pipe market expectations, aiming at supporting the need for change and the potential development of standards that capture recent technological RCP advancements. The study will particularly focus on comparing structural strength examination, hydrostatic pressure performance evaluation and concrete durability measurement provisions in current RCP standards. RCP structural design methodology, hydraulic design as well as the pressure pipe application are not within the scope of the study.

Table 2. List of RCP standards.

\begin{tabular}{ccccc}
\hline Study Area & $\begin{array}{c}\text { Design Standard } \\
\text { and Reference }\end{array}$ & $\begin{array}{c}\text { Materials and } \\
\text { Manufacturing } \\
\text { Specification }\end{array}$ & $\begin{array}{c}\text { Structural } \\
\text { Strength Testing } \\
\text { Standard }\end{array}$ & $\begin{array}{c}\text { Hydrostatic } \\
\text { Performance } \\
\text { Testing Standard }\end{array}$ \\
\hline Canada & $\begin{array}{c}\text { CSA S6 } \\
\text { OCPA Concrete Pipe } \\
\text { Design Manual }\end{array}$ & CSA A257.2 (RCP) & CSA A257.0 & CSA A257.0 \\
USA & $\begin{array}{c}\text { ASCE15 } \\
\text { ACPA Concrete Pipe } \\
\text { Design Manual }\end{array}$ & $\begin{array}{c}\text { ASTM C1765 (SFRCP) } \\
\text { ASTM C1818 (SynFRCP) }\end{array}$ & ASTM C497 & $\begin{array}{c}\text { ASTM C443 } \\
\text { ASTM C1628 }\end{array}$ \\
\hline $\begin{array}{c}\text { United } \\
\text { Kingdom }\end{array}$ & BS EN 1295 & BS EN 1916 (RCP, SFRCP) & BS EN 1916 & BS EN 1916 \\
\hline $\begin{array}{c}\text { Australia \& } \\
\text { New Zealand }\end{array}$ & AS/NZS 3725 & AS/NZS 4058 (RCP) \\
\hline China & AS4139 (FRCP) & AS/NZS 4058 & AS/NZS 4058 \\
\hline
\end{tabular}

Table 3. Acceptance criteria for RCP.

\begin{tabular}{cccccccc}
\hline Study Area & Materials & $\begin{array}{c}\text { Durability } \\
\text { Test }\end{array}$ & $\begin{array}{c}\text { Visual } \\
\text { Inspection }\end{array}$ & $\begin{array}{c}\text { Concrete } \\
\text { Strength }\end{array}$ & $\begin{array}{c}\text { Reinforcement } \\
\text { Placement and Amount }\end{array}$ & $\begin{array}{c}\text { Load } \\
\text { Test }\end{array}$ & $\begin{array}{c}\text { Hydrostatic } \\
\text { Test }\end{array}$ \\
\hline Canada & Yes & Absorption & Yes & Yes & & Yes & Note 1 \\
USA 1 & Yes & Absorption & Yes & Yes & Yes & Cover and amount & Yes \\
USA 2 & & Yes & Yes & & Cover only 2 & Note 2 \\
UK & & Absorption & Yes & & Cover only & Yes & Yes \\
Australia \& & & & Yes & Yes & Cover only & Yes & Yes \\
New Zealand & & & & & & & Yes \\
China & & & & & & & Yes
\end{tabular}

Note 1-owner required; Note 2-joint conform to ASTM C443, C990, C1628 or other specifications.

\subsection{Selection of Study Area}

The study area was selected to cover countries having well-established concrete pipe associations and/or related industrial non-profit regulatory bodies. The US and Canada are selected as a representation of North American standards. The American Standards of Testing and Materials (ASTM) are widely adopted and referenced around the world. British Standards were selected as a representation for European countries and many Commonwealth Nations. Countries such as Malaysia also adopt British Standards for reinforced concrete pipe. Hong Kong, a former British oversea colony, also adopts British Standards for drainage design guides. Australia and New Zealand are part of the front end of pipe technology advancement and were also selected. China, who with about $19 \%$ of the world's population is one of the fastest growing economies in the world, was also 
selected. Its densely populated metropolises experience rapid urbanization along with high demand for infrastructure development including drainage systems, and thus the rationale for including it in this study. Table 4 showed the total population in 2013 covered by the standards studied in this paper.

Table 4. Population of studied area [29].

\begin{tabular}{ccc}
\hline Study Area & Population (Million) & $\%$ \\
\hline Canada & 35 & 0.5 \\
USA & 316 & 4.4 \\
United Kingdom & $64(700)$ & $0.9(9.8)^{*}$ \\
Australia \& New Zealand & 27 & 0.4 \\
China & 1357 & 19.0 \\
Total (Study Area) & 1799 & $25.2(34.1)^{*}$ \\
Total Population & 7137 & \\
\hline
\end{tabular}

* () population of Europe.

\subsection{Terminology and Unit of Measure}

This paper covers multiple international standards. To maintain consistency of definitions, the international system of units (SI units) will be used. Values presented using empirical units in US standards were converted into SI units. Force is measured in newton $(\mathrm{N})$ or kilo-newton $(\mathrm{kN})$. The hydrostatic pressure is measured in kilo-Pascal $(\mathrm{kPa})$. The strength of materials is measured in mega-Pascal (MPa). The length is measured in meters $(\mathrm{m})$ or millimeters $(\mathrm{mm})$. The technical terms used by each country with similar meaning were defined in Table 5 .

Table 5. Terminology.

\begin{tabular}{|c|c|}
\hline Terms & Definition \\
\hline Bell & Female end of pipe, also named socket or groove in some areas. \\
\hline Crack load & $\begin{array}{l}\text { The maximum sustained load without the developed crack in RCP reaching the crack limit. Crack limits } \\
\text { vary depending on the standards of each studied country. }\end{array}$ \\
\hline Design crack load & $\begin{array}{l}\text { Design crack load is the expectation of maximum sustained load without the developed crack in RCP to } \\
\text { reach the crack limit. The design crack load usually depends on the class of the pipe. This load is also } \\
\text { known as proof load in Australia and New Zealand and minimum crushing load in UK. }\end{array}$ \\
\hline Design ultimate load & $\begin{array}{l}\text { The design ultimate load is the expectation of the maximum sustained load that the pipe can withstand } \\
\text { without collapsing. The ultimate load usually is } 50 \% \text { higher that the design crack load. In Canada and US, } \\
\text { the factor reduces to } 25 \% \text { higher for the higher class. }\end{array}$ \\
\hline Effective length & $\begin{array}{l}\text { Length of pipe section after installation including the bell and excluding the spigot OR including the } \\
\text { spigot and excluding the bell, also known as lay length in Canada and US or internal barrel length in UK. }\end{array}$ \\
\hline FRCP & Fiber reinforced concrete pipe (including steel and synthetic fiber). \\
\hline Load test & $\begin{array}{l}\text { Test to determine strength of the pipe in Newtons, also known as the three-edge bearing test or crushing } \\
\text { test. In some areas, the load is based on two edges or four edges. Regardless, the edge load is applied to } \\
\text { the crown and the invert of the pipe parallel to the axis of the pipe. }\end{array}$ \\
\hline Min. crushing load & See Design crack load. \\
\hline Pipe (strength) class & $\begin{array}{l}\text { The direct translation of the crack load. In some areas, such as Canada, the value of the crack load is } \\
\text { normalized. The pipe class is measured in Newtons per meter of pipe per millimeter of inner diameter. In } \\
\text { some other areas, the class is presented in category, e.g., in the US: Class I, II, III, IV and V. }\end{array}$ \\
\hline Proof load & See Design crack load \\
\hline RCP & Reinforced concrete pipe, also called "the pipe" in this document. \\
\hline SFRCP & Steel fiber-reinforced concrete pipe \\
\hline Spigot & Male end of the pipe, also named tongue. \\
\hline SynRCP & Synthetic fiber-reinforced concrete pipe \\
\hline Test crack load & $\begin{array}{l}\text { The actual testing load that the crack reaches the crack limit. The value is recorded during the test. If the } \\
\text { test crack load is greater than the design crack load, the pipe passed the crack load requirement. This load } \\
\text { is also known as three-edge bearing load or D-load in Canada and US. }\end{array}$ \\
\hline Test ultimate load & $\begin{array}{l}\text { The maximum load recorded in the load test of the pipe before losing the strength. If the test ultimate } \\
\text { load is greater than the ultimate load, the pipe passed the ultimate load requirement. This is also known } \\
\text { as collapsed load in UK. }\end{array}$ \\
\hline Three-edge bearing load & Three-edge bearing load: see Test Crack Load; Three-edge bearing test: See Load Test \\
\hline Ultimate load & The maximum sustained load that the pipe can withstand. \\
\hline
\end{tabular}




\section{Products and Materials Requirements}

\subsection{Geometrical Requirements}

The pipe's geometrical requirements including size, wall thickness, shape, and joint profile provide not only hydraulic capacity, but also structural strength to withstand overburden earth and live loads. Joint design provides necessary hydraulic continuity and hydrostatic performance. Australia and New Zealand offer the widest pipe size range from $100 \mathrm{~mm}$ to $4200 \mathrm{~mm}$ in inner diameter, while Canada and the US offer sizes between $300 \mathrm{~mm}$ to $3600 \mathrm{~mm}$. The RCP size is limited by its mass and dimensions not to exceed logistic limits of local transportation authorities. Each study area offers multiple wall thickness specifications for various pipe classes. Increasing the pipe's wall thickness allows for more space to accommodate the reinforcing steel, thus increasing flexural and shear strength. In Canada and the US, there are three types of wall thickness classes named A, B and C; each type is mathematically related to the size of the pipe inner diameter as illustrated in Equation (1).

$$
W T=\frac{I D}{300}+x(\text { Wall A }) ; W T=\frac{I D}{300}+25.4(\text { Wall B }) ; W T=\frac{I D}{300}+38.1(\text { Wall C })
$$

where: $x$ varies from 0 to $19.1 \mathrm{~mm}$ for $900 \mathrm{~mm}-300 \mathrm{~mm}$ pipe diameter; $x=0$ for pipe diameter of $975 \mathrm{~mm}$ or larger. $I D=$ pipe nominal size in $\mathrm{mm}$; WT = pipe wall thickness in $\mathrm{mm}$

It is necessary to control tolerances on pipe geometrical characteristics to ensure that the above-mentioned properties meet the requirements.

Table 6 compares the tolerances of the pipe inner diameter and wall thickness among all study areas. The US and Canada have tighter inner diameter tolerances of $\pm 5 \mathrm{~mm}$ for smaller size pipes (e.g., 300-mm) and $\pm 9 \mathrm{~mm}$ for larger size pipes (e.g., $3000 \mathrm{~mm}$ ), respectively. China has a tighter wall thickness tolerance of $-2 \mathrm{~mm}$ for the $300 \mathrm{~mm}$ to $675 \mathrm{~mm}$ pipe diameter range, and $-5 \mathrm{~mm}$ for $3000 \mathrm{~mm}$ pipe diameter. Canada does not have an upper limit for wall thickness if walls thicker than specified will not reduce the strength of the pipe. In the UK, the tolerance for pipe size is not found in the specifications. However, the requirement for the joint tolerance is specified in BS EN 1916:2002 Section 4.3.4 in relation to durability evaluation.

Table 6. Tolerance requirements for pipe size and wall thickness (mm).

\begin{tabular}{ccccccccc}
\hline \multirow{2}{*}{ Size } & \multicolumn{3}{c}{ Inner Diameter Tolerance } & \multicolumn{3}{c}{ Wall Thickness Tolerance } \\
\cline { 2 - 8 } & Canada & US & AS/NZ & China & Canada & US & AS/NZ & China \\
\hline 300 & \pm 5 & \pm 6 & \pm 7 & $+4 /-8$ & $-3 /+$ & \pm 3 & $-3 /+5$ & $-2 /+8$ \\
450 & \pm 7 & \pm 8 & \pm 7 & $+4 /-8$ & $-3 /+$ & \pm 3 & $-4 /+5$ & $-2 /+8$ \\
600 & \pm 9 & \pm 9 & \pm 7 & $+4 /-8$ & $-4 /+$ & \pm 4 & \pm 5 & $-2 /+8$ \\
675 & \pm 7 & \pm 7 & \pm 8 & $+4 /-8$ & $-4 /+$ & \pm 4 & \pm 6 & $-2 /+8$ \\
900 & \pm 9 & \pm 9 & \pm 8 & $+6 /-10$ & $-5 /+$ & \pm 5 & \pm 7 & $-3 /+10$ \\
1200 & \pm 10 & \pm 9 & \pm 8 & $+6 /-10$ & $-5 /+$ & \pm 5 & \pm 8 & $-3 /+10$ \\
1500 & \pm 10 & \pm 9 & \pm 10 & $+6 /-10$ & $-5 /+$ & \pm 5 & \pm 9 & $-3 /+10$ \\
1800 & \pm 10 & \pm 9 & \pm 13 & $+8 /-12$ & $-5 /+$ & \pm 5 & \pm 10 & $-4 /+12$ \\
2400 & \pm 10 & \pm 9 & \pm 13 & $+8 /-12$ & $-5 /+$ & \pm 5 & \pm 10 & $-4 /+12$ \\
3000 & \pm 10 & \pm 9 & \pm 13 & $+10 /-14$ & $-5 /+$ & \pm 5 & \pm 10 & $-5 /+14$ \\
\hline
\end{tabular}

In terms of effective length, standards in Canada and the US require that the pipe be not less than $10 \mathrm{~mm}$ per meter length, or $13 \mathrm{~mm}$ whichever is less. Australia and New Zealand have an effective length tolerance of $15 \mathrm{~mm}$; and China allows tolerances of $18 \mathrm{~mm}$ over and $12 \mathrm{~mm}$ under. The effective length has a relatively greater tolerance since the impact on the overall length of the pipeline is less significant and field adjustment is usually made. The square-ness of the end face of the pipe is determined by comparing the effective length measurement on opposite sides of the pipe. Out of square-ness on the end face will result in misalignment of the pipeline. Excessive or uneven gap will also pose a threat to joint performance. Australia and New Zealand have the most stringent 
tolerances of 2 to $10 \mathrm{~mm}$ between $300 \mathrm{~mm}$ to $3000 \mathrm{~mm}$ of inner pipe diameter. Canada and the US allow up to $20 \mathrm{~mm}$ for $3000 \mathrm{~mm}$ diameter pipe. Table 7 provides a full comparison of pipe end face square-ness in standards. Standards in Canada and the US do not specify geometric measurement methods. However, the quality program describes the use of go-and-no-go gauge in evaluating the size and joint tolerance; and the inspection of the steel header and pallet, which forms the pipe joint. Australia and New Zealand specify that such measurements should be taken at right angles and at a specific location along the pipe. A mean value shall be taken from the results of internal diameter measurements. The length of the pipe shall be taken at three one-third points around the circumference. In China, the geometric measurement seems to be the most stringent among all pipe performance measures. Specific measurement methods for inner diameter, measurement points, joint geometry, effective length, thickness, straightness and square-ness are defined.

Table 7. Maximum variation in length between opposite sides ( $\mathrm{mm}$ ).

\begin{tabular}{cccc}
\hline Size & CAN/US & AS/NZ & China \\
\hline 300 & 6 & 2 & 10 \\
450 & 6 & 2 & 10 \\
600 & 6 & 3 & 10 \\
675 & 7 & 3 & 10 \\
900 & 9 & 5 & 10 \\
1200 & 12 & 6 & 12 \\
1500 & 15 & 8 & 15 \\
1800 & 16 & 9 & 15 \\
2400 & 20 & 10 & 15 \\
3000 & 20 & 10 & 15 \\
\hline
\end{tabular}

\subsection{Concrete for Precast Pipe}

The mechanical strength of concrete provides the rigidity of the pipe to withstand various types of loads, including earth load, live load, fluid load and induced load due to bedding and installation. Typical compressive strength specifications for concrete used in pipes are listed in Table 8 . Strength evaluation relies mostly on quality control cylinders cast from the concrete mixture during the pipe's manufacturing process. Core samples from the actual pipe are usually an acceptable alternative though undesirable due to the often-tight spacing of the reinforcing steel. The compressive strength standard requirements for Canada and the US vary from $28 \mathrm{MPa}$ to $42 \mathrm{MPa}$, depending on the pipe size and class. Higher class and/or larger pipe size require higher compressive strength. Some standards specify $40 \mathrm{MPa}$ regardless of the pipe class and size. In China, additional factors are applied to the cylinder compressive strength to account for different manufacturing processes. These factors are $1.25,1.0,1.0$, and 1.5 for pipes made by the centrifuging process, packer head, vertical vibration, and vibrational pressing, respectively.

Table 8. 28-day Compressive strength requirements.

\begin{tabular}{|c|c|c|c|c|c|}
\hline Study Areas & Class 1 & Class 2 & Class 3 & Class 4 & Class 5 \\
\hline Canada & - & $\begin{array}{l}\text { 50D: } \\
30 \mathrm{MPa} \leq 2400 \mathrm{~mm} \\
35 \mathrm{MPa}>2400 \mathrm{~mm}\end{array}$ & $\begin{array}{l}65 \mathrm{D}: \\
30 \mathrm{MPa} \leq 2100 \mathrm{~mm} \\
35 \mathrm{MPa}>2100 \mathrm{~mm}\end{array}$ & $\begin{array}{l}\text { 100D: } \\
30 \mathrm{MPa} \leq 1350 \mathrm{~mm} \\
35 \mathrm{MPa}>1350 \mathrm{~mm}\end{array}$ & $\begin{array}{l}\text { 140D: } \\
40 \mathrm{MPa} \text { all size }\end{array}$ \\
\hline US & $\begin{array}{l}\text { CL1: } \\
28 \mathrm{MPa} \leq 2400 \mathrm{~mm} \\
34 \mathrm{MPa}>2400 \mathrm{~mm}\end{array}$ & $\begin{array}{l}\text { CL2: } \\
28 \mathrm{MPa} \leq 2400 \mathrm{~mm} \\
34 \mathrm{MPa}>2400 \mathrm{~mm}\end{array}$ & $\begin{array}{l}\text { CL3: } \\
28 \mathrm{MPa} \leq 2100 \mathrm{~mm} \\
34 \mathrm{MPa}>2100 \mathrm{~mm}\end{array}$ & $\begin{array}{l}\text { CL4: } \\
28 \mathrm{MPa} \leq 1350 \mathrm{~mm} \\
\text { (B-wall) or } \\
35 \mathrm{MPa} \text { larger dia. } \\
1650 \mathrm{~mm} \text { (C-wall) }\end{array}$ & $\begin{array}{l}\text { CL5: } \\
42 \mathrm{MPa} \text { all size }\end{array}$ \\
\hline UK & \multicolumn{5}{|c|}{$40 \mathrm{MPa}$ all sizes and classes } \\
\hline $\begin{array}{l}\text { Australia \& } \\
\text { New Zealand }\end{array}$ & \multicolumn{5}{|c|}{ Not specified in the materials standard } \\
\hline China & \multicolumn{5}{|c|}{$40 \mathrm{MPa}$ all size and class } \\
\hline
\end{tabular}




\subsection{Conventional Reinforcement and Concrete Cover}

Conventional concrete pipe reinforcement including carbon steel reinforcing rebar, welded cold drawn wire cage, and welded wire fabric provide the post-crack behavior of RCP. Among these, cold drawn wire cage is the most commonly used option because of its cost-effective manufacturing process and flexibility in design. Using cold drawn wire spiral cage (Figure 2), wire size and spacing selection do not affect the labor involved, which provides cost advantages. Deformed wire cage was introduced in late 1960s, providing bond effectiveness between steel and concrete [7]. Its relatively higher tensile strength (500 MPa) compared to conventional carbon steel (400 MPa) reduces the amount of needed reinforcement. Depending on the pipe's size and wall thickness, the cage configuration can be categorized into single cage, double cage, or triple cage with elliptical cage (Figure 3). In special cases, such as pipe jacking, the elliptical cage is sometimes replaced with heavier outer and inner cages; or double outer and/or inner cages. The pipe's structural capacity, especially its flexural strength, is extremely sensitive to the placement of the cage. Generally, the area of steel located in the inner face of the pipe invert and crown governs the flexural capacity. Additional stirrups may be required in the upper and lower haunch areas for shear and radial tension resistance, especially in larger and higher pipe class. The cage placement can be determined by examination of the concrete clear cover. This inspection is required by most examined standards, but not all of which make this a rejection criterion.
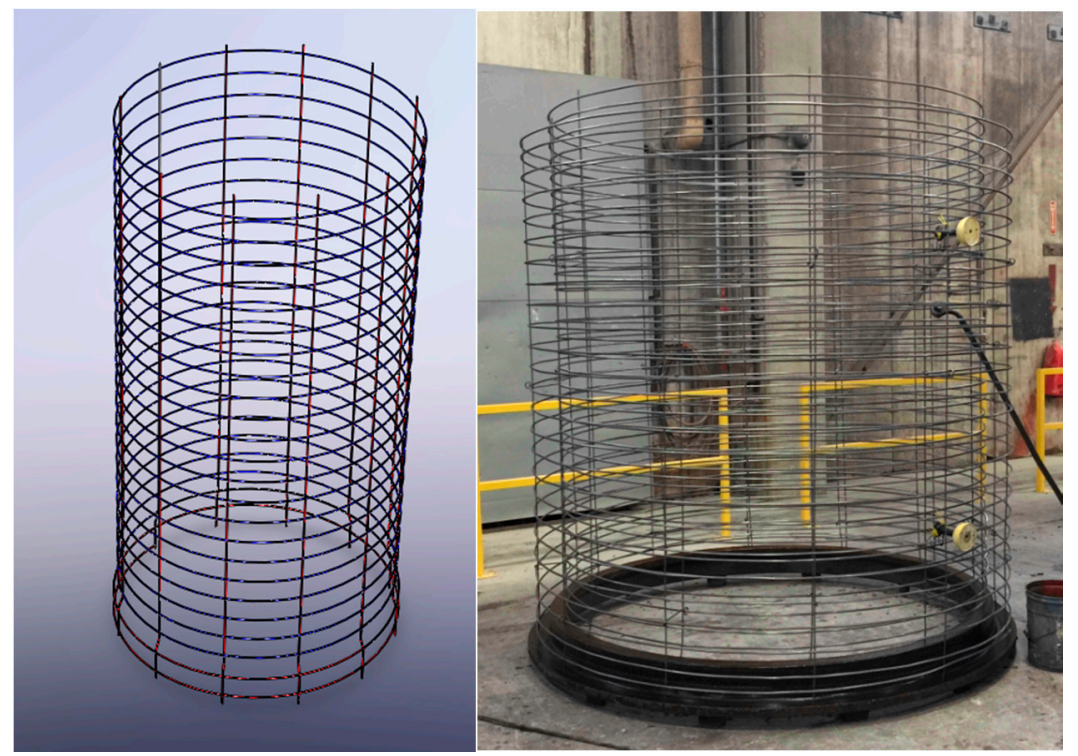

Figure 2. (left) Concrete single spiral reinforcing cage isometric model (right) double cages staged on the pallet ready for pipe production.

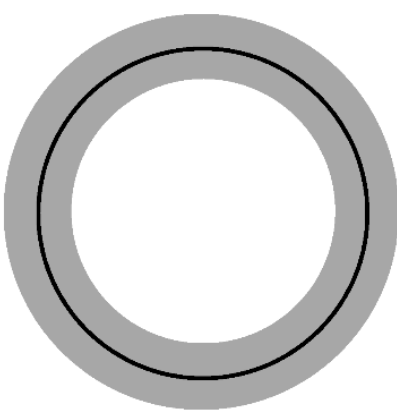

(a) Single Cage

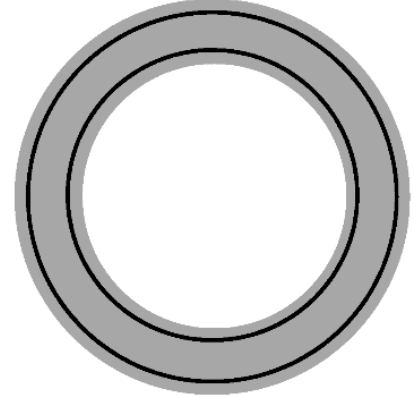

(b) Double Cage

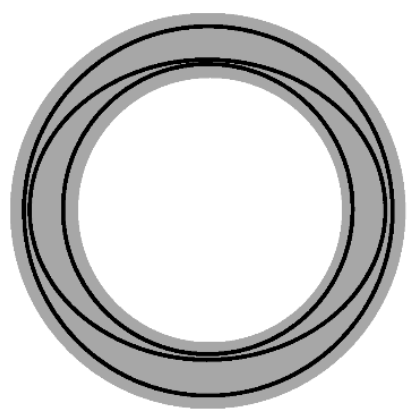

(c) Triple Cage

Figure 3. Concrete reinforcing cage configuration. 
In Canada, the requirement to inspect the placement of reinforcement is optional depending on the requirement of the owner. The quality of the placement is usually reflected in the load test. If the permissible variation exceeds the minimum cover, the pipe is still acceptable if its capacity meets or exceeds the target crack load and ultimate load. In the US, the pipe may be accepted based on either of the following options: conducting the load test, which does not require the inspection of the cage placement; or to fully inspect the steel amount, cage placement and concrete cover, which exempts the destructive load test. The UK, Australia, New Zealand, and China require the inspection of the concrete cover regardless of the load test result. In addition, the concrete cover offers a protective barrier against the ingress of harmful species such as sulfate and chloride ions. Given the same concrete quality in an aggressive environment, the larger the cover the longer is the allowed time for chloride ions to penetrate and reach the reinforcing steel and initiate corrosion.

Table 9 lists the minimum concrete cover requirements in relationship to fabrication for each study area. In terms of concrete cover thickness, a minimum of 13-mm is specified in Canada and the US, without specifying the exact measurement method or how measurements are recorded. In contrast, China requires full concrete cover measurements to be carried out at three specific locations along the pipe axis with each location having three points spaced at 120 degrees apart around the circumference. These measurements are taken by exposing the reinforcing steel.

Table 9. Concrete cover requirements.

\begin{tabular}{|c|c|c|c|}
\hline Study Area & Condition & Permissible Limit & Mating Surface \\
\hline \multirow[t]{5}{*}{ Canada/US } & Single cage & $\begin{array}{l}\text { Place at } 35-50 \% \text { from } \\
\text { inner wall, } \min 13 \mathrm{~mm}\end{array}$ & Spigot $6.5 \mathrm{~mm}$ to the circumf. Wire \\
\hline & & & Bell $13 \mathrm{~mm}$ to the circumf. wire \\
\hline & Double/multiple cages: & & \multirow{3}{*}{ No restriction to the longitudinal wire } \\
\hline & Wall $<63 \mathrm{~mm}$ & $19 \mathrm{~mm}, \min 13 \mathrm{~mm}$ & \\
\hline & Wall $\geq 63 \mathrm{~mm}$ & $25 \mathrm{~mm}, \min 13 \mathrm{~mm}$ & \\
\hline UK & General condition & $\begin{array}{l}15 \mathrm{~mm} \text { or max aggregate } \\
\text { size whichever is larger * }\end{array}$ & Not specified \\
\hline \multirow{5}{*}{$\begin{array}{l}\text { Australia/New } \\
\text { Zealand }\end{array}$} & Dry Cast & Barrel ** & Mating surface ${ }^{* *}$ \\
\hline & Wall $\leq 25 \mathrm{~mm}$ & $6 /-\mathrm{mm}$ & $4 /-\mathrm{mm}$ \\
\hline & $25 \mathrm{~mm}<$ wall $\leq 35 \mathrm{~mm}$ & $8 /-\mathrm{mm}$ & $5 /-\mathrm{mm}$ \\
\hline & Wall > $35 \mathrm{~mm}$ & $10 / 20 \mathrm{~mm}$ & $6 / 10 \mathrm{~mm}$ \\
\hline & Wet Cast (50 MPa) & $25 / 35 \mathrm{~mm}$ & $25 / 35 \mathrm{~mm}$ \\
\hline \multirow{3}{*}{ China } & Wall $\leq 40 \mathrm{~mm}$ & Min $10 \mathrm{~mm}$ cover & \multirow{3}{*}{ Not specified } \\
\hline & $40 \mathrm{~mm}<$ Wall $\leq 100 \mathrm{~mm}$ & Min $15 \mathrm{~mm}$ cover & \\
\hline & Wall > $100 \mathrm{~mm}$ & Min $20 \mathrm{~mm}$ cover & \\
\hline
\end{tabular}

* BS 5911-1:2002 Section 6.1.1; ${ }^{* *}$ Minimum cover for normal exposure/marine exposure.

\section{Product Strength Evaluation}

\subsection{Pipe Strength Classification}

Pipe strength is a common way to classify concrete pipes. The class either reflects the normalized load values or is presented by a sequential category number or alphabetically. In Canada, the RCP class represents the design crack load in Newtons per meter length per millimeter inner diameter that the pipe can withstand. For example, 65-D represents a pipe that can withstand $65 \mathrm{~N}$ per meter length per millimeter inner diameter, known as the design load, without a single crack reaching the crack limit. This is a normalized value, which can be translated into the minimum design crack load required in the load test by multiplying the inner diameter and the actual length of the pipe specimen (Equation (2)). The pipe is also required to be tested to its ultimate capacity. A minimum safety factor of 1.5 must be exceeded for 100-D pipes or lower, and 1.25 for 140-D pipes or higher.

$$
D L=C \times I D \times L \text { and } \mathrm{UL}=\mathrm{SF} \times \mathrm{DL}
$$


where: $D L=$ design crack load in $\mathrm{N} ; C=$ class of pipe in $\mathrm{N} / \mathrm{m} / \mathrm{mm} ; I D=$ inner diameter in $\mathrm{mm}$; $L=$ effective length in $\mathrm{m}$; $\mathrm{UL}=$ ultimate load; $\mathrm{SF}=$ safety factor.

In the UK, the pipe class represents the design ultimate load in kilo-newton per meter length and per meter diameter of the pipe. For example, Class 120 indicates that the pipe can withstand $120 \mathrm{kN}$, known as collapse load or crush load, per meter length per meter inner diameter without collapsing. The design crack load is specified as $67 \%$ of the design ultimate; hence $80.4 \mathrm{kN} / \mathrm{m} / \mathrm{m}$ for Class 120 pipe. This is equivalent to a safety factor of 1.5 between the design crack load and ultimate load.

The load requirements of each class in the US are equivalent to those in Canada, except that the class is represented by sequential numbers instead of the load. Class 2, 3, 4, and 5 in the US are equivalent to 50-D, 65-D, 100-D and 140-D in Canada. China, Australia and New Zealand also use sequential numbers to represent pipe strength category. Class 1 and Class 2 in China are equivalent to Class 1 and Class 3 in the US, respectively. The design crack load requirements of each class specified in Australia and New Zealand do not have a linear relationship to the pipe size. The required design crack load, known as proof load, for each class is listed in Table 4.2 in AS/NZ 4058:2007 [30]. For example, Class 6 is closer to 140-D in Canada when the pipe diameter is smaller than 450-mm, but 100-D when the diameter is larger than $2100 \mathrm{~mm}$. Figures 4 and 5 display the load class comparison among the study areas. The linearity and non-linearity are also portrayed in Figure 6 with the pipe strength at crack load is normalized to Newton per meter length pipe per mm inner diameter.

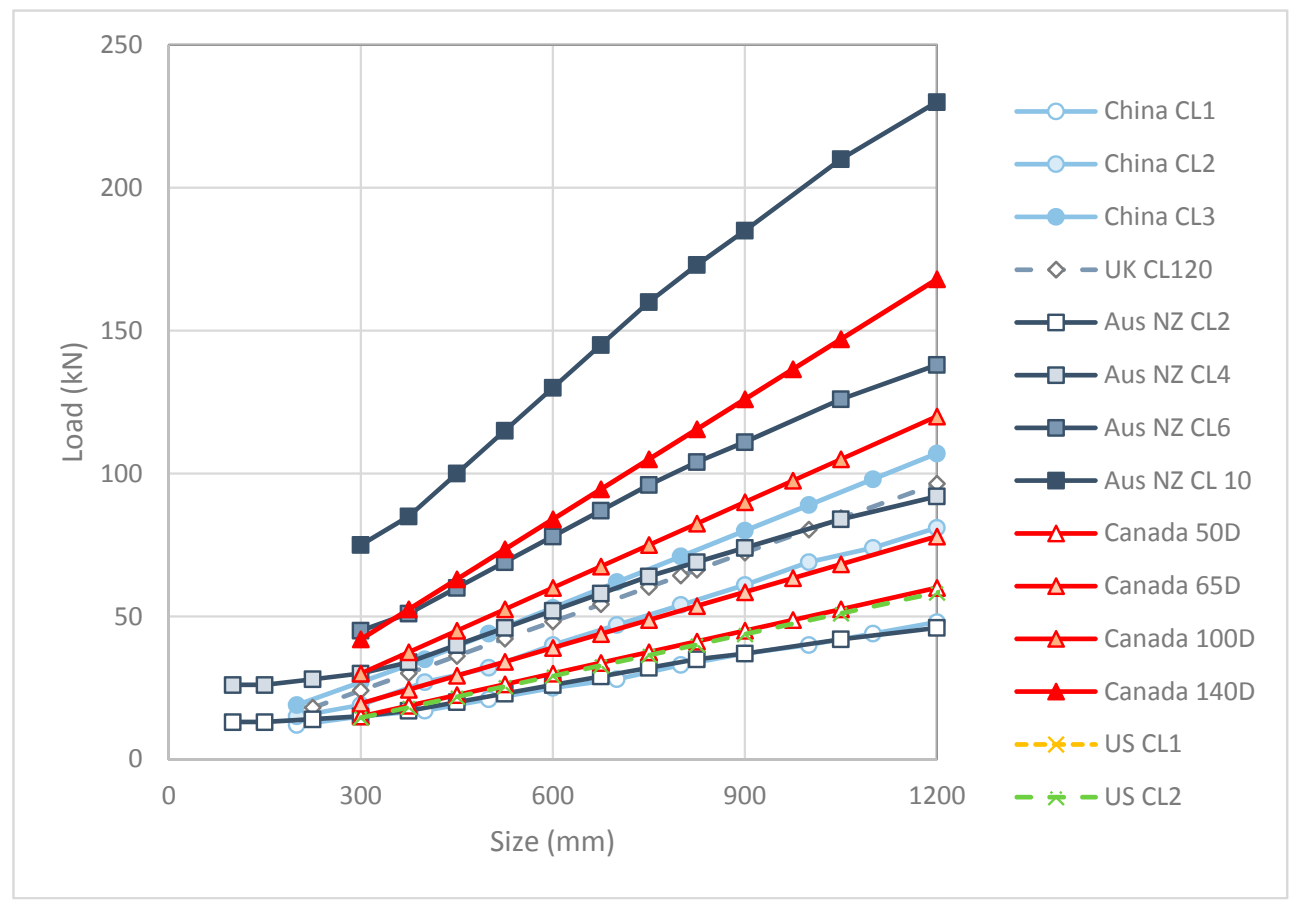

Figure 4. Comparison of crack load in various standards (1200 mm diameter pipe or under). 


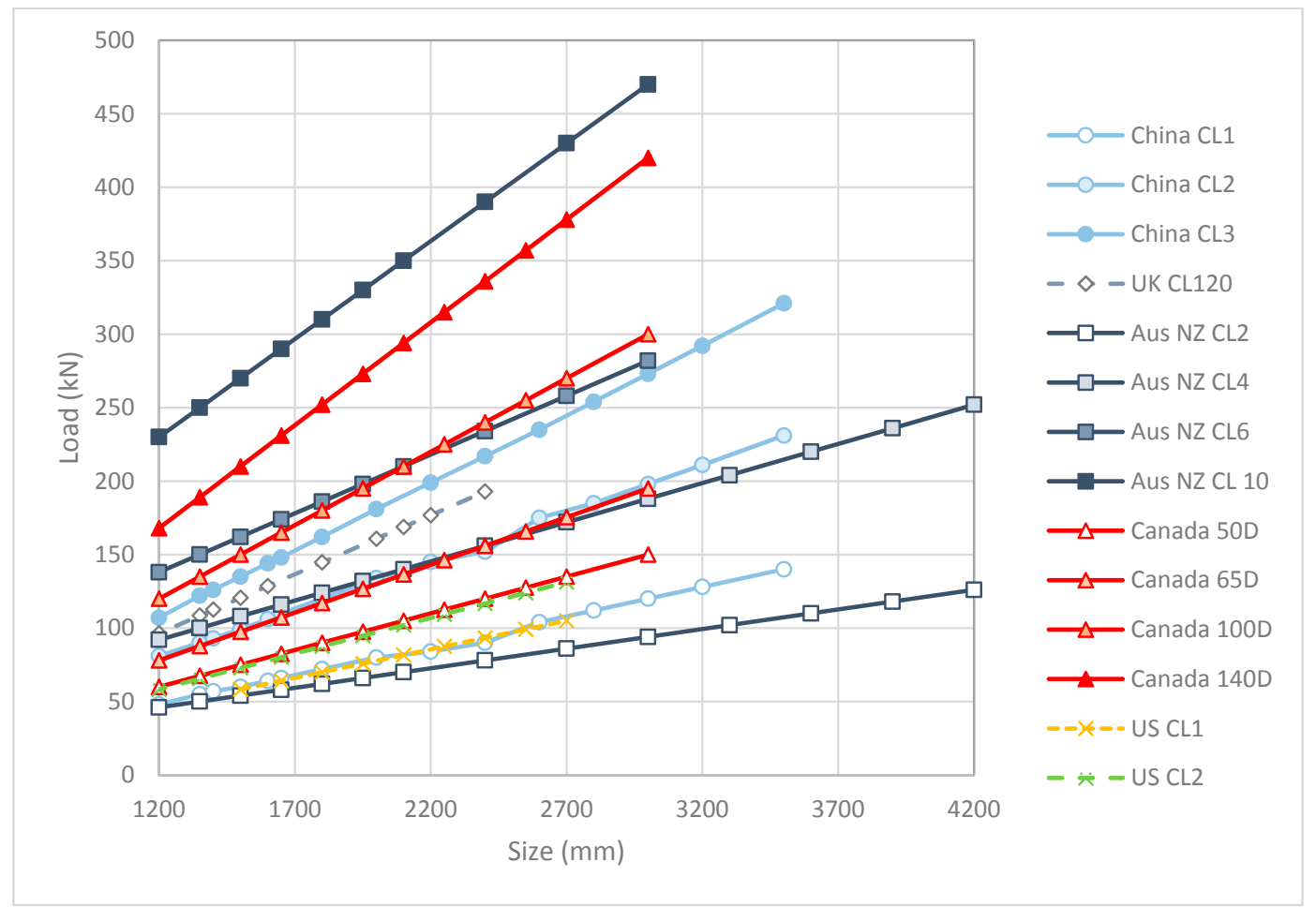

Figure 5. Comparison of crack load in various standards (1200 mm dimeter pipe or larger).

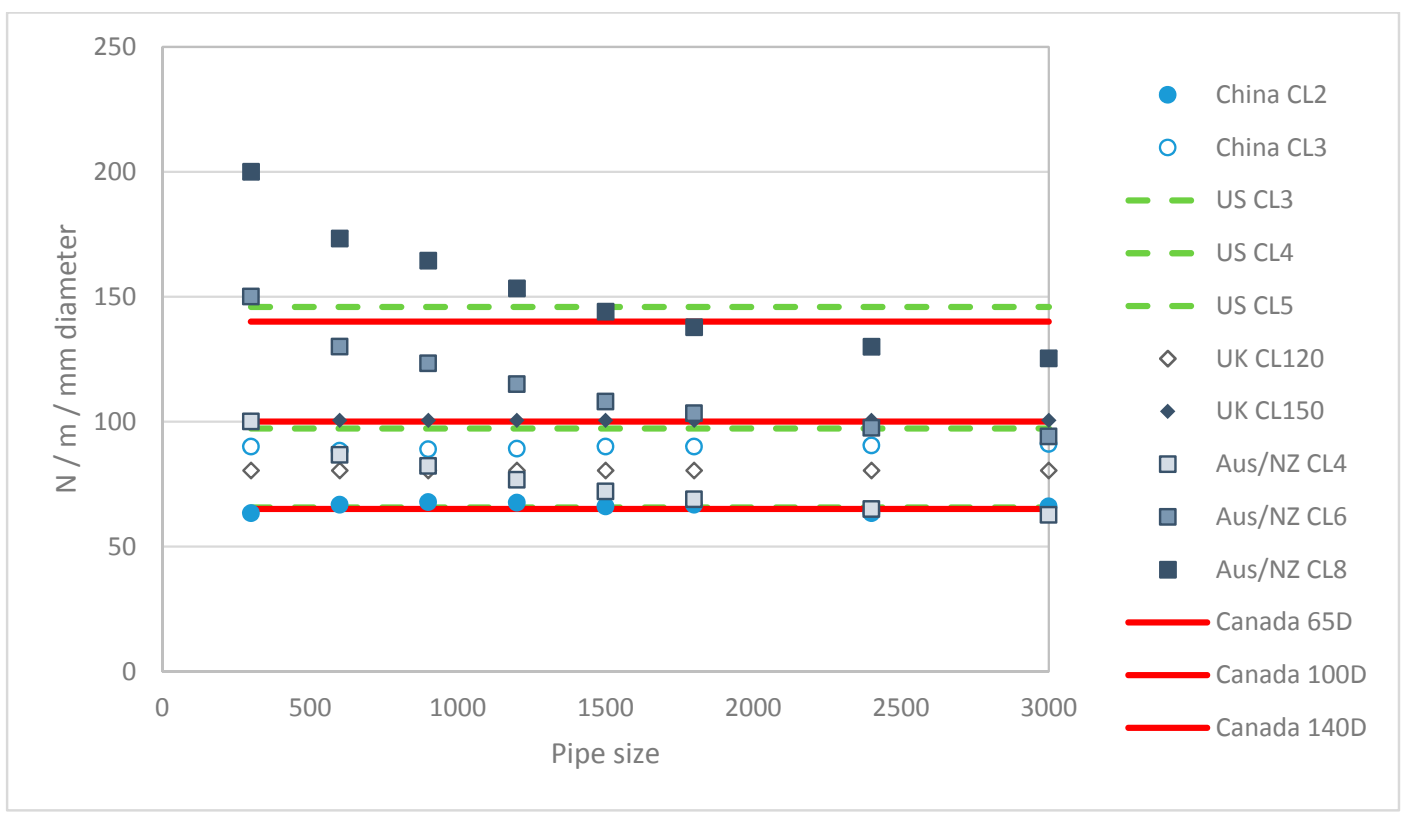

Figure 6. Comparison of normalized design crack load in various standards.

\subsection{Structural Load Test}

The structural load test, also known as the three-edge bearing test, is a destructive test that has been commonly adopted to evaluate the crack load and ultimate load of RCP. The test has over 100 years of history indicating its success in RCP assessment [31]. This is a primary acceptance test among all study areas, though the examination process and interpretation of the test results are slightly different. In common, the testing procedure is to apply load evenly on a vertical plane along the crown 
of the pipe and the pipe axis. The load definition and terminology vary among study areas and are translated for consistency in Table 5.

Figure 7 illustrates load progression during the three-edge bearing test and the critical load definitions. The load in most procedures is applied to the pipe either in continuous or discrete manner. The inspector examines the crack development by measuring the crack width and length using a crack gauge. Subsequently, the load is carried to the design crack load and in some study areas, the pipe is loaded to failure. Figure 8 illustrates based on specification requirement the progression of the load test for each study area. The load is normalized and the load rate is assumed to be an average from the specification for comparison purpose. The definition of the crack limit for each study area is different. The crack load is defined when the judgmental crack width and length occur. The ultimate load is defined as the maximum applied load on the pipe, which is identical among all study areas. The definition of crack limit determination, testing procedure, crack load and ultimate load are summarized in Table 10.

Table 10. Load test summary.

\begin{tabular}{|c|c|c|c|c|c|}
\hline $\begin{array}{l}\text { Procedure and } \\
\text { Setup }\end{array}$ & Canada & US & UK & $\begin{array}{c}\text { Australia/New } \\
\text { Zealand }\end{array}$ & China \\
\hline $\begin{array}{l}\text { Load orientation } \\
\text { (Figure 9) }\end{array}$ & Three edges & Three edges & $\begin{array}{l}\text { Three edges } \\
\text { Four edges }\end{array}$ & $\begin{array}{l}\text { Two edges } \\
\text { Three edges }\end{array}$ & Three edges \\
\hline $\begin{array}{c}\text { Load rate } \\
(\mathrm{kN} / \mathrm{min} / \mathrm{m})\end{array}$ & $7-37$ & $\begin{array}{c}\operatorname{Max} 109.4 / 43.8 \\
\operatorname{Max} 43.8\end{array}$ & $20-25$ & Min 10 & 30 \\
\hline $\begin{array}{l}\text { Load } \\
\text { incrementation to } \\
\text { crack load }\end{array}$ & $\begin{array}{l}\text { Continuous to } \\
\text { design and } \\
\text { actual crack } \\
\text { load }\end{array}$ & $\begin{array}{l}\text { Continuous to } \\
\text { design and } \\
\text { actual crack } \\
\text { load }\end{array}$ & $\begin{array}{l}\text { Load to design } \\
\text { crack load and } \\
\text { hold for crack } \\
\text { inspection }\end{array}$ & $\begin{array}{l}\text { Load to design crack } \\
\text { load and hold for crack } \\
\text { inspection remove the } \\
\text { load and re-inspect the } \\
\text { crack. }\end{array}$ & $\begin{array}{l}\text { Load to } 80 \% \text { DL } \\
\text { Step load until } \\
\text { crack load is } \\
\text { determined } \\
\text { Hold load at each } \\
\text { interval }\end{array}$ \\
\hline $\begin{array}{l}\text { Load } \\
\text { incrementation to } \\
\text { ultimate load }\end{array}$ & $\begin{array}{l}\text { Continuous } \\
\text { from crack load } \\
\text { to ultimate } \\
\text { (collapse) load } \\
\text { if needed }\end{array}$ & $\begin{array}{l}\text { Continuous } \\
\text { from crack load } \\
\text { to ultimate } \\
\text { (collapse) load } \\
\text { if needed }\end{array}$ & $\begin{array}{c}\text { Continuous to } \\
\text { ultimate (collapse) } \\
\text { load }\end{array}$ & $\begin{array}{l}\text { Continuous to design } \\
\text { ultimate load }\end{array}$ & $\begin{array}{l}\text { Load } 80 \% \text { UL } \\
\text { Increase at an } \\
\text { interval until } \\
\text { collapsed. } \\
\text { Hold load for } \\
\text { inspection }\end{array}$ \\
\hline $\begin{array}{l}\text { Crack limit under } \\
\text { crack load }\end{array}$ & $\begin{array}{c}0.3 \mathrm{~mm} \text { wide } \times \\
300 \mathrm{~mm} \text { long }\end{array}$ & $\begin{array}{l}0.3 \mathrm{~mm} \text { wide } \times \\
300 \mathrm{~mm} \text { long }\end{array}$ & $\begin{array}{c}0.3 \mathrm{~mm} \text { wide } \times 300 \\
\mathrm{~mm} \text { long }\end{array}$ & $\begin{array}{c}0.15-0.25 \mathrm{~mm}^{* *} \times 300 \\
\mathrm{~mm} \text { long }\end{array}$ & $\begin{array}{c}0.2 \mathrm{~mm} \times 300 \\
\mathrm{~mm} \text { long }\end{array}$ \\
\hline $\begin{array}{c}\text { Allowable crack } \\
\text { width (w/o load) }\end{array}$ & Not specified & Not specified & $\begin{array}{c}0.15 \mathrm{~mm} \times 300 \mathrm{~mm} \\
\text { long }\end{array}$ & $\begin{array}{c}0.1-0.2 \mathrm{~mm}^{* * *} \times 300 \\
\mathrm{~mm} \text { long }\end{array}$ & $0.05 \mathrm{~mm}$ \\
\hline Measuring tool & Crack gauge & Crack gauge & Not specified & Crack gauge & Crack gauge \\
\hline $\begin{array}{c}\text { Crack load } \\
\text { determination }\end{array}$ & $\begin{array}{l}\text { Actual crack } \\
\text { load }\end{array}$ & $\begin{array}{l}\text { Actual crack } \\
\text { load }\end{array}$ & $\begin{array}{l}\text { Design crack load } \\
\text { (Pass/Fail) }\end{array}$ & $\begin{array}{l}\text { Design crack load } \\
\text { (Pass/Fail) }\end{array}$ & Actual crack load \\
\hline $\begin{array}{l}\text { Ultimate load } \\
\text { determination }\end{array}$ & $\begin{array}{c}\text { Actual ultimate } \\
\text { load }\end{array}$ & $\begin{array}{l}\text { Actual ultimate } \\
\text { load }\end{array}$ & $\begin{array}{l}\text { Actual ultimate } \\
\text { load }\end{array}$ & $\begin{array}{l}\text { Design ultimate load } \\
\text { (Pass/Fail) }\end{array}$ & $\begin{array}{c}\text { Actual ultimate } \\
\text { load }\end{array}$ \\
\hline
\end{tabular}

${ }^{*}$ Up to $75 \%$ Max $109.4 \mathrm{kN} / \mathrm{min} / \mathrm{m}, 75-100 \%$ DL Max $43.8 \mathrm{kN} / \mathrm{min} / \mathrm{m}$; ${ }^{* *}$ Crack width depends on concrete cover under applied load. ${ }^{* * *}$ Crack width depends on concrete cover after load removed. 


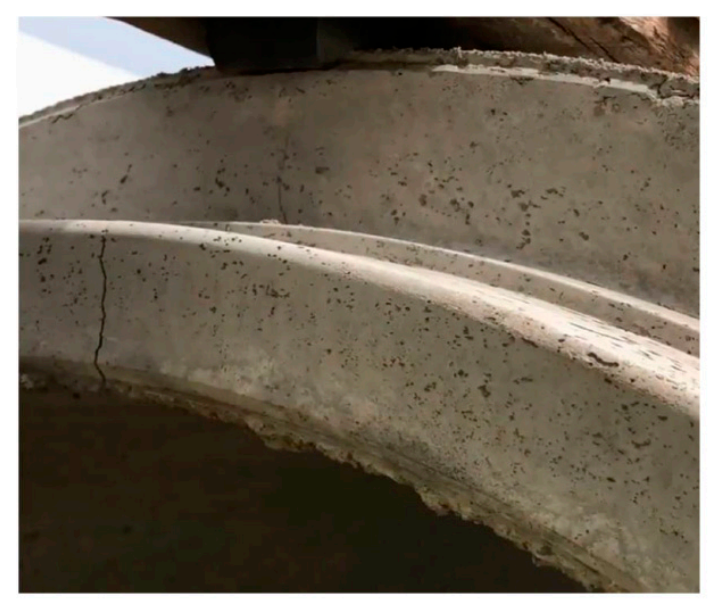

(a) Hairline crack grows into design crack

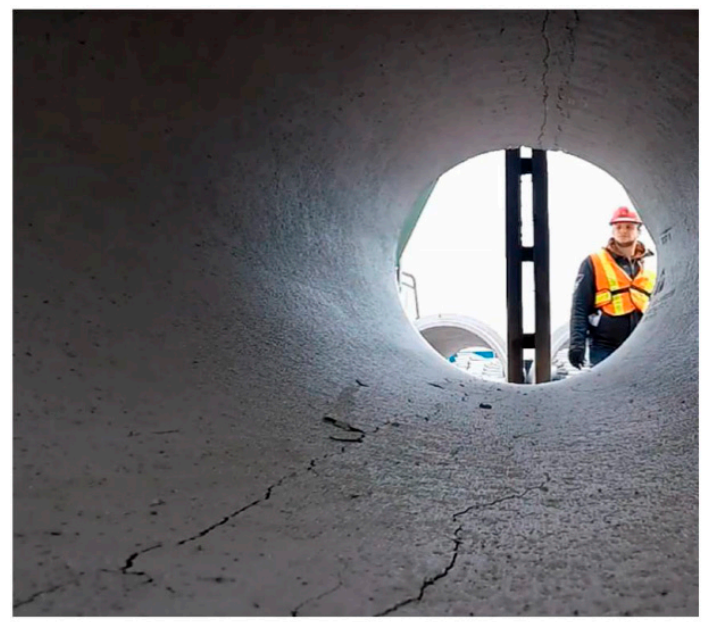

(c) Cracks develop beyond design crack width

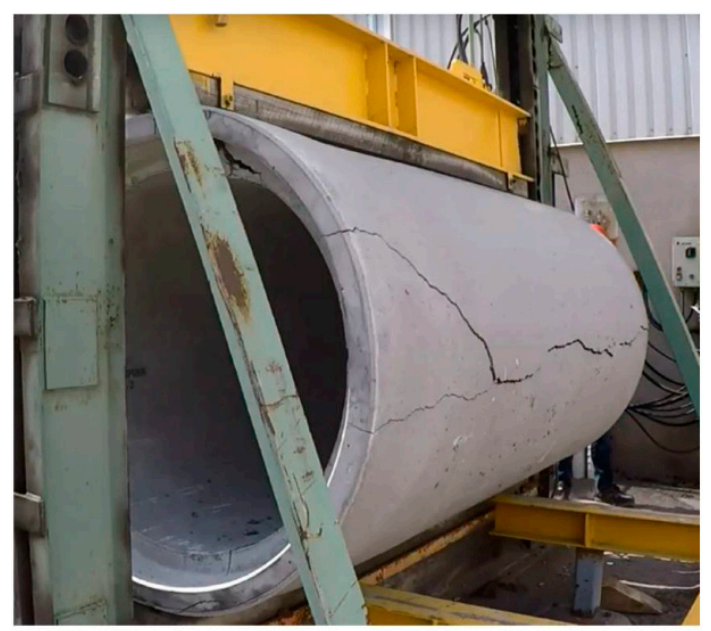

(d) Test approach ultimate load

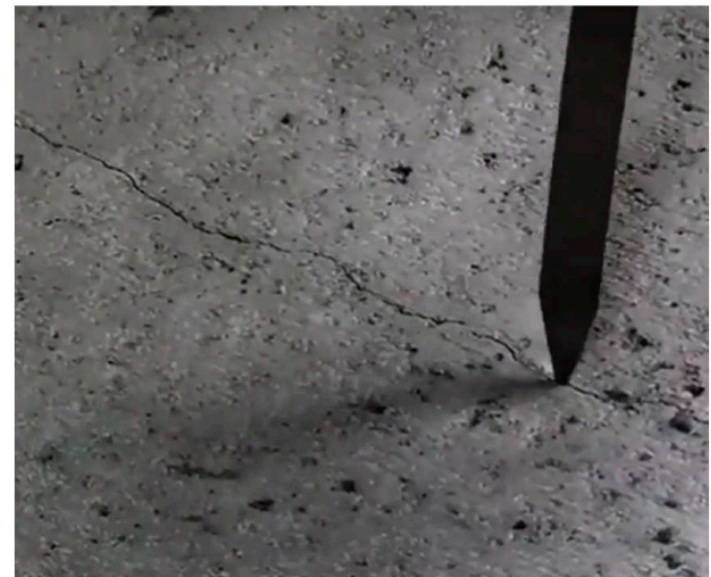

(b) Measure for design crack width
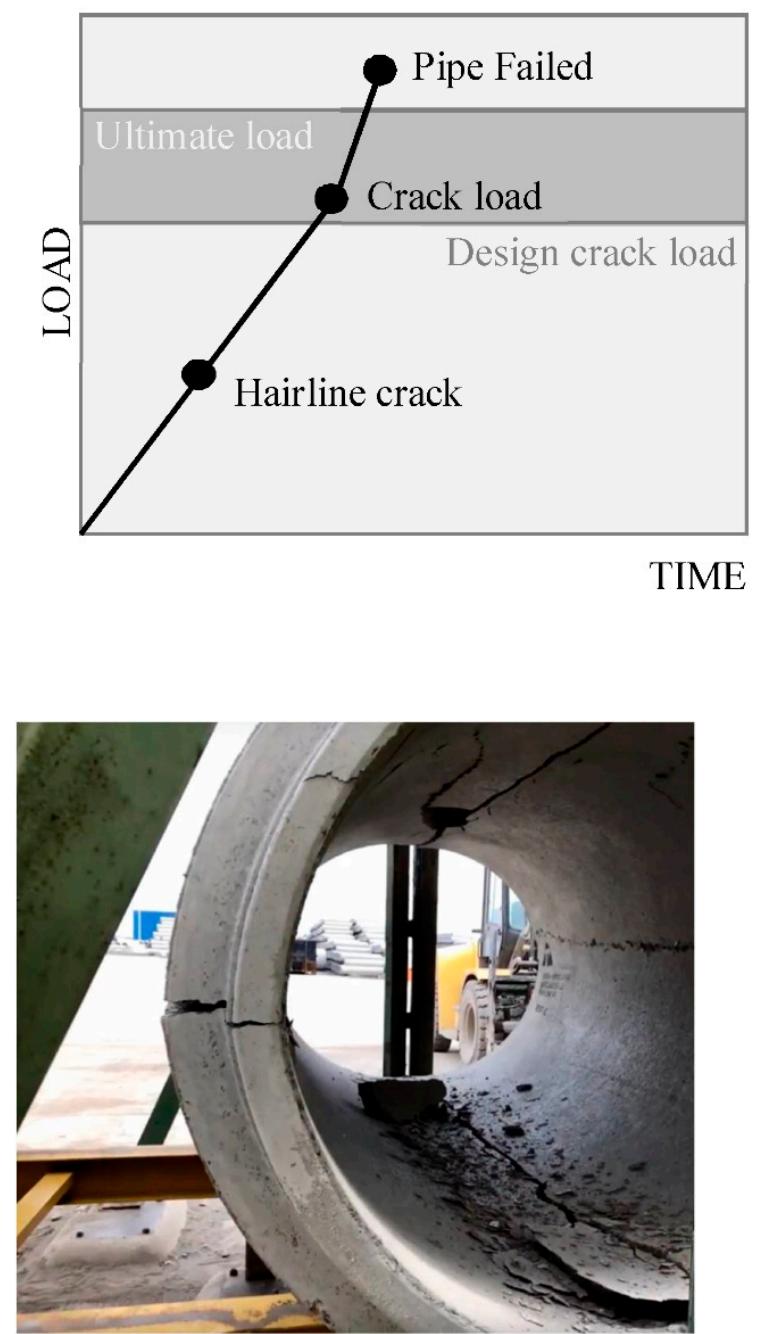

(e) Pipe damage at ultimate load

Figure 7. Load test progression. 


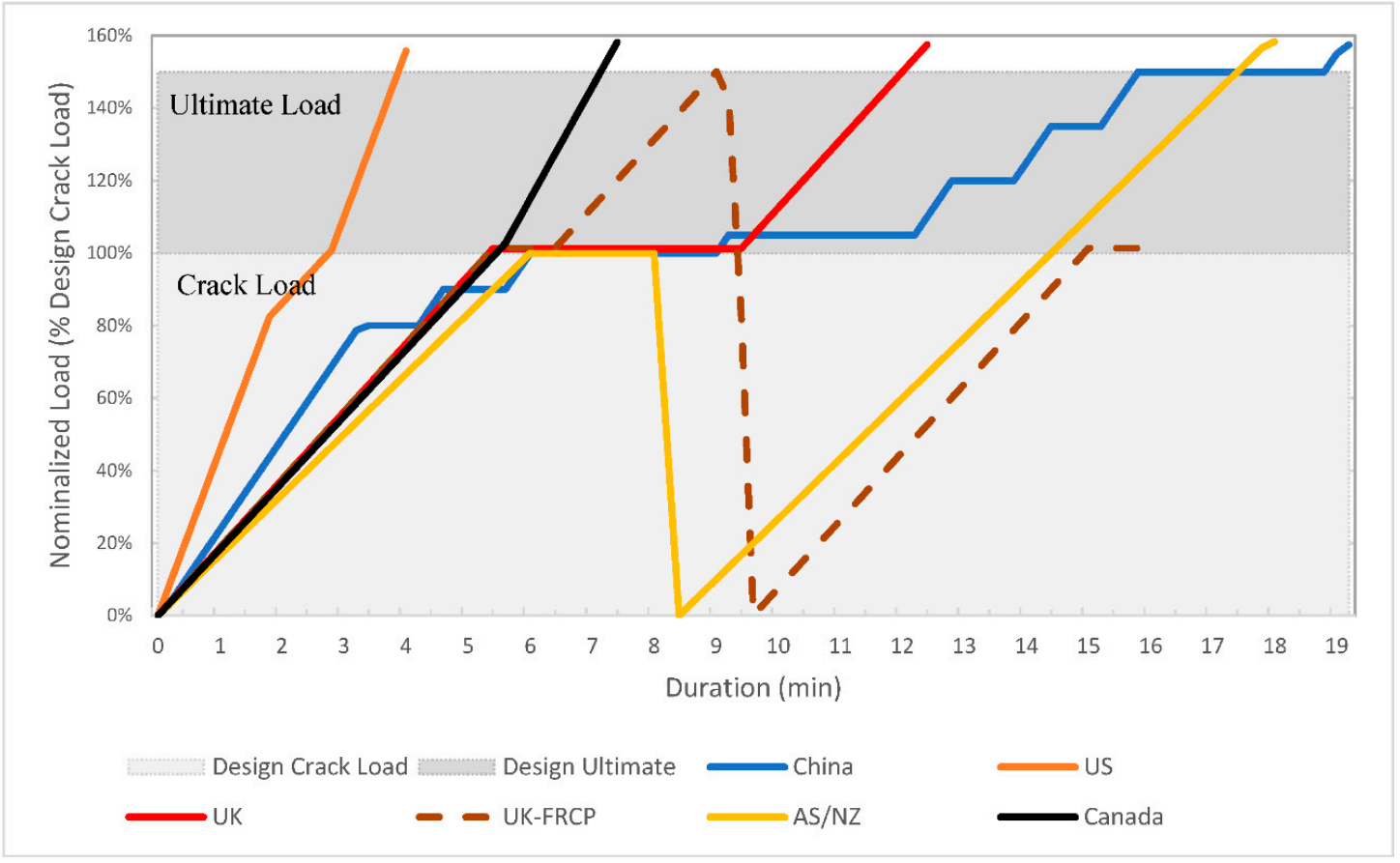

Figure 8. Comparison of load test progression in various standards.

\subsubsection{Canada and US}

The load test in Canada and the US are governed by CSA 257.0-14 [32] Section 4 and ASTM C497-15 [33] Section 4, respectively. Both testing procedures and crack measurement criteria are very similar, except for the unit conversion between imperial and metric and the loading rate. The crack limit is defined as $0.3 \mathrm{~mm}$ (0.01 inch) wide and $300 \mathrm{~mm}$ (12 inches) long. The applied loading rate is between 7 and $37 \mathrm{kN} / \mathrm{min} / \mathrm{m}$ in Canada until the formation of crack that meets the crack limit. In the US, a faster loading rate up to $109.4 \mathrm{kN} / \mathrm{min}$ before reaching $75 \%$ of the design crack load is followed by a slower rate of $43.8 \mathrm{kN} / \mathrm{min} / \mathrm{m}$ until the actual crack limit is reached. There is no limitation of the loading rate after the crack load is determined up until failure. In the entire process, the load increment is continuous without a pulse for crack inspection. The inspector will need to focus on spotting the crack, measure, and determine that the crack limit is reached. The load value is then recorded. This could be a difficult task depending on the number of inspectors, their experience and their judgement. After the crack load is determined, the pipe is then loaded to failure. The maximum load that the pipe can withstand is recorded. The class of the pipe is calculated based on the crack load and the ultimate load divided by the safety factor, whichever is smallest. In the US, the design strength and ultimate strength of the pipe are expressed in pound per linear foot.

\subsubsection{United Kingdom}

The load test in the UK also includes fiber-reinforced concrete pipe (FRCP) and is outlined in BS EN 1916-2002 [11] Annex C. The standard details the bearing strip dimensions and three typical load arrangements. The space between the bearing strips is determined by the 30-degree angle in between them and is larger than that in all other study areas Figure 9c. For example, for a $1200 \mathrm{~mm}$ pipe with $125 \mathrm{~mm}$ wall thickness, the space between bearing strips is calculated to be about $380 \mathrm{~mm}$ in comparison to $100 \mathrm{~mm}$ in Canada and the US. For larger diameter pipe (>1200 mm), the load test with four contact points (two top, two bottom) is also an option (Figure 9d). An adjustment factor of 0.64 is applied to the test result calculation to account for the additional load angle. In terms of loading procedure, the loading rate is in between 20 and $25 \mathrm{kN} / \mathrm{min} / \mathrm{m}$. The load selection is to be held at the design crack load to allow for crack inspection. The standard also requires crack stability to 
be monitored. If the crack limit is not reached and the cracks are stable, the pipe is considered to be in conformance to the required class. For examining the ultimate load, the pipe is loaded to failure. If the actual ultimate load is greater than the design ultimate load, the pipe is considered to be in conformance to the specified class. In this standard, there is an alternative option (basic inspection option). A reduced testing frequency (half of the regular inspection) is permitted. Where the basic inspection mode is selected, the target crack load is increased to $80 \%$ of the design ultimate from $67 \%$, and the target ultimate is increased to $120 \%$ of the design ultimate. This provides extra safety to compensate for the probability of failure.

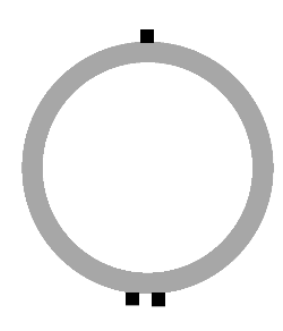

(a) Three-edge bearing

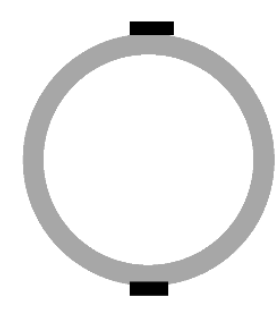

(b) Two-edge bearing $(\mathrm{AS} / \mathrm{NZ})$

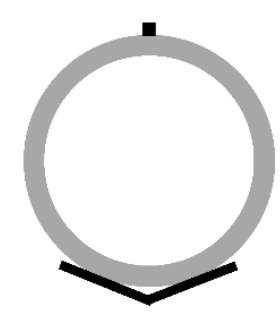

(c) Three-edge bearing (UK)

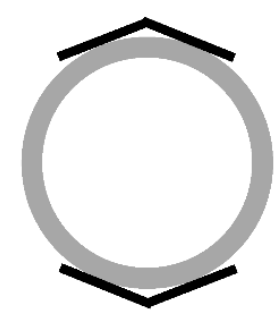

(d) Four-edge bearing (UK)

Figure 9. Illustration of various pipe load test orientations in standards.

\subsubsection{Australia and New Zealand}

In Australia and New Zealand, the load test is governed by AS/NZS 4058-2007 [30]. The pipe and load orientation are similar to the three-edge bearing arrangement. However, this is the only standard considered that allows vertical setup as an alternative arrangement. In this test, the pipe is loaded at a rate exceeding $10 \mathrm{kN} / \mathrm{min} / \mathrm{m}$ until the design crack load value. The load needs to be held for crack inspection at that point. Then, the load is removed for crack inspection. When the load is removed, the crack width shall be $0.05 \mathrm{~mm}$ less than the crack under the sustained design crack load. The crack width defined in this standard also varies depending on the concrete cover. The crack width limit is listed in Table 11. Various thicknesses of measuring gauge (feeler gauge shown in Figure $7 \mathrm{~b}$ ) are being used in measuring the crack width. The measurement needs to be taken at six consecutive points along the same crack for a pass-fail decision. In the ultimate load test, the specimen is tested to the maximum load and shall exceed the design ultimate load for the corresponding class and size to maintain conformity.

Table 11. Crack limit (AS/NZS 4058:2007).

\begin{tabular}{ccc}
\hline Concrete Cover & Pipe Loaded & Load Removed \\
\hline$\leq 10 \mathrm{~mm}$ & $0.15 \mathrm{~mm}$ & $0.10 \mathrm{~mm}$ \\
Between $10 \mathrm{~mm}$ and $20 \mathrm{~mm}$ & $0.20 \mathrm{~mm}$ & $0.15 \mathrm{~mm}$ \\
$\geq 20 \mathrm{~mm}$ & $0.25 \mathrm{~mm}$ & $0.20 \mathrm{~mm}$ \\
\hline
\end{tabular}

\subsubsection{China}

The load test in China is specified in GB/T 16752-2006 [34]. Figure 8 shows this stepwise loading process. The arrangements of pipes and loads are very close to that in Canada and the US. However, the crack width limit is $0.2 \mathrm{~mm}$ with no definition of crack length. The load is applied to the specimen at a rate of $30 \mathrm{kN} / \mathrm{min} / \mathrm{m}$ and is held for $1 \mathrm{~min}$ for crack inspection when it reaches $80 \%$ of the design crack load. If no crack is observed or the crack width is less than the threshold, the load will be increased at an interval of $10 \%$ of the design crack load with a 1-min hold period at each interval, until reaching the predefined crack load. Crack inspection is conducted at each load pause. If the crack 
width is still less than the limit of $0.2 \mathrm{~mm}$, the load is continued at $5 \%$ of the design crack load interval with 3-min hold period for examination until the $0.2 \mathrm{~mm}$ crack width is observed and the crack load is then recorded. To continue the load test towards ultimate, the load is applied to and held at $80 \%$ of the design ultimate load for $1 \mathrm{~min}$. The load is then continued at $10 \%$ of the design ultimate load interval with a 1-min hold period at each interval until the predefined ultimate load is reached. A 3-min hold period is required for crack and damage inspection. If the pipe has not reached the ultimate load limit, loading is continued at intervals of $5 \%$ of the design ultimate load followed by a 3-min hold period to allow stabilization of the crack and crack inspection. The last step is repeated until the pipe reaches the maximum load. In this loading exercise, if the load causing the crack limit and ultimate limit occurs during the load increment process, the previous load interval value becomes the official crack load or ultimate load for reporting, respectively.

\section{Hydrostatic Performance and Joint Design}

Hydrostatic performance, one of the main requirements for a gravity sewer pipe, is primarily based on joint design, concrete permeability, flexible sealants such as gasket, and installation quality. The expected hydrostatic performance is measured through a quality control hydrostatic test conducted under controlled conditions to examine the ability of pipe or pipelines (multiple pipe sections) in withstanding the internal hydrostatic pressure. Figure 10 illustrates various hydrostatic test set ups adopted in the study areas. The controlled conditions include complete alignment, deflected position and joint under shear load. The duration for the pressure to be held varies from as short as $30 \mathrm{~s}$ to $1 \mathrm{~h}$; hence the test cannot be equated to the actual installed condition. The process of validating the hydrostatic performance of RCP in terms of definition of pressure targets, joint design, testing methods, and acceptance criteria is outlined below. Leakage in this test is defined as water dripping through the joint or any part of the concrete pipe during the test. Moisture or beads of water appearing on the surface of the wall or at the joint are not considered leakage. Table 12 summarized the internal hydrostatic performance requirements of each study area.

Table 12. Hydrostatic performance test summary.

\begin{tabular}{|c|c|c|c|c|c|c|c|}
\hline $\begin{array}{l}\text { Study } \\
\text { Area }\end{array}$ & $\begin{array}{l}\text { \# of Test } \\
\text { Pipes }\end{array}$ & Test Ori. & Straight Alignment & Deflection & $\begin{array}{l}\text { Differential } \\
\text { (Shear) Load }\end{array}$ & $\begin{array}{c}\text { Joint } \\
\text { Shear Test }\end{array}$ & $\begin{array}{c}\text { Other } \\
\text { Requirements }\end{array}$ \\
\hline Canada & 3 & Horizontal & $103 \mathrm{kPa}(10 \mathrm{~min})$ & $90 \mathrm{kPa}(10 \mathrm{~min})$ & $\begin{array}{l}35 \mathrm{kPa} \text { at } 10 \mathrm{~min} \\
45 \mathrm{kN} \text { shear load }\end{array}$ & $\begin{array}{l}\text { Shear load } \\
\text { during } \\
\text { hydro }\end{array}$ & $\begin{array}{l}\text { Owner's } \\
\text { requirement Not } \\
\text { required if size } \\
\text { larger than } \\
1200 \mathrm{~mm}\end{array}$ \\
\hline US & 2 & $\begin{array}{l}\text { Horizontal } \\
\text { or Vertical }\end{array}$ & $90 \mathrm{kPa}(10 \mathrm{~min})$ & $69 \mathrm{kPa}(10 \mathrm{~min})$ & Not required & $\begin{array}{c}\text { Shear load } \\
\text { without } \\
\text { hydro }\end{array}$ & $\begin{array}{l}\text { Owner's } \\
\text { requirement }\end{array}$ \\
\hline UK & 2 & Horizontal & $50 \mathrm{kPa}(15 \mathrm{~min})$ & $50 \mathrm{kPa}(15 \mathrm{~min})$ & $50 \mathrm{kPa}$ for $15 \mathrm{~min}$ & $\begin{array}{l}50 \mathrm{kPa} \text { for } \\
15 \mathrm{~min}\end{array}$ & $\begin{array}{l}\text { Not required if } \\
\text { wall is thicker } \\
\text { than } 125 \mathrm{~mm}\end{array}$ \\
\hline China & 1 & $\begin{array}{l}\text { Horizontal } \\
\text { or Vertical }\end{array}$ & $\begin{array}{c}60 \mathrm{kPa} \text { CL1 }(10 \mathrm{~min}) \\
100 \mathrm{kPa} \text { CL2 \& } \\
3(10 \mathrm{~min})\end{array}$ & Not specified & Not specified & - & $\begin{array}{l}\text { Not required if } \\
\text { wall is thicker } \\
\text { than } 150 \mathrm{~mm}\end{array}$ \\
\hline $\begin{array}{l}\text { Australia/New } \\
\text { Zealand }\end{array}$ & N & $\begin{array}{l}\text { Horizontal } \\
\text { or Vertical }\end{array}$ & $\begin{array}{c}90 \mathrm{kPa}(90 \mathrm{~s} / 10 \mathrm{~mm} \\
\text { wall thickness) }\end{array}$ & Not specified & Not specified & - & 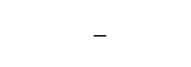 \\
\hline $\begin{array}{l}\text { Australia/New } \\
\text { Zealand }\end{array}$ & N & Horizontal & $\begin{array}{c}90 \mathrm{kPa} \leq 0.6 \\
\mathrm{~mL} / \mathrm{mm} / \mathrm{m} \text { loss } \\
\text { rate in } 1 \mathrm{~h}\end{array}$ & Not specified & Not specified & - & - \\
\hline $\begin{array}{l}\text { Australia/New } \\
\text { Zealand }\end{array}$ & $N$ & Horizontal & $\begin{array}{c}\mathrm{P}_{\text {spec }}=\text { pressure } \\
\text { rating } \\
\mathrm{P}_{\text {test }}=1.2 \mathrm{P}_{\text {spec }} \\
\mathrm{P}_{\text {ult }}=1.5 \mathrm{P}_{\text {spec }} \text { for } \\
30 \mathrm{~s}\end{array}$ & Not specified & Not specified & Yes & $\begin{array}{l}\text { Contract } \\
\text { requirement }\end{array}$ \\
\hline
\end{tabular}




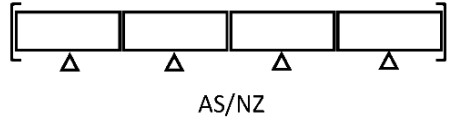

(a) Four pipe sections aligned

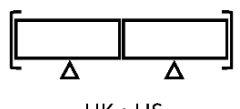

(c) Two pipe sections aligned

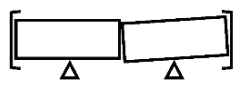

UK $\cdot$ US

(f) Two pipe sections deflected

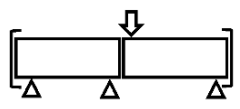

UK

(h) Two pipe sections under shear load

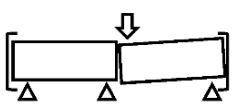

UK $\cdot$ US

(j) Two pipe sections under shear load and deflection

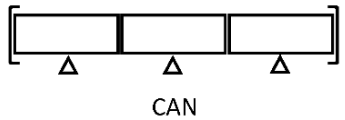

(b) Three pipe sections aligned

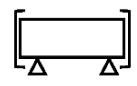

$\mathrm{AS} / \mathrm{NZ} \cdot \mathrm{CHN}$

(d) One pipe section

horizontal setup

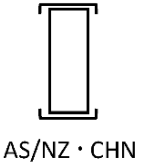

(e) One pipe section vertical setup

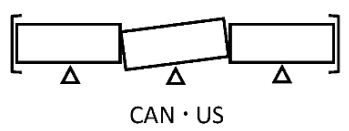

(g) Three pipe sections deflected

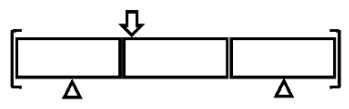

CAN

(i) Three pipe sections under shear load

Figure 10. Illustration of various hydrostatic test setup standard configurations.

\subsection{Pipe Hydrostatic Performance in Canada}

CSA A257.3 [32] specifies the RCP joint requirements, which include the internal hydrostatic test, physical test of the joint materials, and inspection requirement of joint design. This standard also stipulates that the infiltration requirement shall be quantified by the owners and the testing in the installed position shall be conducted due to those factors beyond the manufacturing of the pipe. The hydrostatic test detailed in CSA A257.0 [32] Section 7 consists of three testing positions: Straight alignment, maximum deflected position and joints under differential load, as illustrated in Figure 10b,g,i, respectively. The testing requires three pipe sections installed horizontally in between bulkheads. Two joints are being tested simultaneously. In the straight alignment, the setup is internally and hydrostatically pressurized to $103 \mathrm{kPa}$ for $10 \mathrm{~min}$ to assess leakage. In the deflected position, the middle section is deflected by creating a joint gap to the maximum of $13 \mathrm{~mm}$ on one side. This position is intended to create the worst possible misalignment in the field. The setup is required to be pressurized to $90 \mathrm{kPa}$ for $10 \mathrm{~min}$ followed by leakage observation. In the final position, the middle section is suspended. The additional weight includes the pipe and water mass to create a maximum differential load of $25 \mathrm{kN}, 35 \mathrm{kN}$ and $45 \mathrm{kN}$ for $300 \mathrm{~mm}, 375 \mathrm{~mm}$ and $450 \mathrm{~mm}$, and $525 \mathrm{~mm}$ pipes or larger, respectively. The purpose of applying the differential load at each side of the joint is to create a joint offset for maximum permissible annular gap leading to the least effective pressure seal from the gasket. Under this setup, the target pressure, therefore, is reduced to $35 \mathrm{kPa}$ for $10 \mathrm{~min}$. The hydrostatic test is satisfied only if the tests in all positions passed. 


\subsection{Pipe Hydrostatic Performance in US}

Hydrostatic performance is not a rejection criterion in ASTM C76 [35]. ASTM C76 refers to testing standards ASTM C443 [36], ASTM C990 [37], and ASTM C1628 [38] at the discretion of the owner. The test is conducted using two pipe sections connected based on the joint design assembly. The pipe sections are plugged with two bulkheads and pressurized to the design target. In ASTM C443, joint performance using rubber gasket is defined for a watertight joint of concrete pipe to be able to withstand $90 \mathrm{kPa}$ of pressure without leakage. The test is performed via two pipe specimens with the test joint in between. As illustrated in Figure 10a,c, straight alignment position and maximum deflected position are required. The internal pressure is held for $10 \mathrm{~min}$ at $90 \mathrm{kPa}$ for straight alignment and $69 \mathrm{kPa}$ for maximum deflected position with the joint being opened to $13 \mathrm{~mm}$ on one side. ASTM C990 details the physical requirement of the sealant materials, design of the joints, testing method for sealants and the performance of the joints. It requires the pipe specimens to be stacked vertically and to internally pressurize the test joint to $69 \mathrm{kPa}$ for $10 \mathrm{~min}$. This standard also states that the test is not intended to simulate the installation or pressure at service level, but only used as quality control. ASTM C1628 addresses the design of the joint for circular and non-circular gaskets, testing methods for gaskets and hydrostatic performance with the same pressure target as ASTM C443, and allows alternatively for external testing if there is no objection from the owner. In addition, the manufacturer has an option to combine the joint structural test and the hydrostatic test to prove the water tightness under load.

\subsection{Pipe Hydrostatic Performance in Australia and New Zealand}

When a watertight joint is specified in the non-pressure sewerage and drainage pipe, AS/NZS 4058 requires a test pressure of $90 \mathrm{kPa}$ to be reached. In New Zealand, there are specifically two options to achieve $90 \mathrm{kPa}$ pressure: a single pipe test or a pipeline test consisting of four test sections, as illustrated in Figure 10a,d,e, respectively. In New Zealand, water loss is permitted in the pipeline test (four test pipes in an aligned position) if the loss is less than $0.6 \mathrm{~mL}$ per hour per mm diameter per meter length. For example, four pieces of $600 \mathrm{~mm}$ diameter RCP with $2.5 \mathrm{~m}$ lay length will allow water loss up to $3.6 \mathrm{~L}$ per hour. In Australia and New Zealand, a contract may specify greater than or equal to $50 \mathrm{kPa}$ and ultimate pressure test. In this case, the test pressure needs to reach at least $20 \%$ more than the specified allowable working pressure. The ultimate pressure shall also reach the lesser of $50 \%$ more than the allowable working pressure or $20 \%$ more plus $75 \mathrm{kPa}$. In addition, the hydrostatic test in a deflected position and a position under differential load are not required. However, the joint assembly test for the pipes with flexible joints is detailed in Appendix $\mathrm{H}$ of the standard. The test is conducted using two pipe sections with maximum deflection between them. A visual assessment is required on the joint gap, positive overlapping between the bell and spigot and damage if applicable. However, no hydrostatic performance is being conducted in this position.

\subsection{Pipe Hydrostatic Performance in UK}

The UK is the only study area which assesses the joint durability due to tightening. The procedure of the test records the deformation and tightening force or pressure in comparison to the calculated values in order to evaluate the durability. This is detailed in Annex A of the standard. Annex E comprises a hydrostatic performance test that is similar to that in the other study areas. A two-pipe setup illustrated in Figure 10c,f, $\mathrm{h}$ for an aligned position, a deflected position and a position under differential load, respectively requires the internal hydrostatic pressure to exceed $50 \mathrm{kPa}$ for $15 \mathrm{~min}$. In the deflected position, the amount of deflection is created based on 12,500 per diameter in millimeters or $50 \mathrm{~mm}$, whichever is smaller. For $300-\mathrm{mm}, 600-\mathrm{mm}$ and $900-\mathrm{mm}$ diameter pipes, the required deflection can be created by a joint gap of 42-mm, 20-mm, and 14-mm, respectively. For 1200-mm pipe, the deflection will be created from a 10-mm joint gap. In the position under shear load, the load is applied to the spigot end of a pipe supported by the joint. A differential load in kilo-newton of 0.03 times the diameter is applied. For example, for a $1200-\mathrm{mm}$ pipe, the load is calculated to be $36 \mathrm{kN}$. 
The manufacturer may combine the deflection and the differential load together with reduction of the differential load to 0.01 times the diameter instead of 0.03 . All positions require a target pressure of $50 \mathrm{kPa}$, which implies minimum requirement regardless of site conditions. Pipes with wall thickness larger than $12 \mathrm{~mm}$ are exempted from this test.

\subsection{Pipe Hydrostatic Performance in China}

Like all other study areas, the internal hydrostatic pressure test is one of the RCP performance criteria. The target pressure is based on the class of the pipe. Class 1 requires the internal pressure to be $60-\mathrm{kPa}$. Classes 2 and 3 require the internal pressure to be $100-\mathrm{kPa}$. Pipes with walls thicker than $150-\mathrm{mm}$ are exempted from this test. The test pipe is setup in horizontal or vertical orientation with bulkheads on both ends of the pipe. The target pressure is introduced within one minute and held for $10 \mathrm{~min}$. The operator is required to look for signs of leakage at the end of the test. However, since only one pipe section is required in the test, it does not assess the joint performance, nor does it evaluate deflected or differential load conditions against hydrostatic pressure.

\section{Concrete Pipe Durability}

Gravity sewer pipe is expected to have up to 75 years of design life [22]. The concrete pipe industry has been promoting up to 100-year design life. RCP may be subjected to thermal contractions, shrinkage, creep, leaching, sulfate attack, freeze thaw cycling, alkali-aggregate reactions, biogenic corrosion and chloride-ions induced corrosion, bacterial effects, abrasion, and sustained mechanical load [22]. Although typical $\mathrm{pH}$ in natural ground conditions is not usually detrimental, low $\mathrm{pH}$ conditions may prevail in ground water. Aerobic bacteria activities in sewerage create acidic environments causing damage by biogenic sulfuric acid attack. Porosity and cracks allow chloride ions to penetrate and further corrode the reinforcing steel. In reviewing RCP standards, measuring concrete porosity and defining allowable crack widths are primary methods to ensure the required durability expectation.

\subsection{Absorption Test}

A water absorption test is specified by pipe standards to evaluate porosity in the hydrated cement paste of the pipe as a durability measure. Porosity depends on the water-to-cement ratio and degree of cement hydration. The higher the interconnected porosity, the easier hostile species such as chloride and sulfate ions can penetrate concrete, thus posing higher risk of reinforcing steel corrosion and concrete deterioration. Absorption is the major test adopted by most RCP standards in the study area. Table 13 summarizes the absorption test limits and requirements among the study areas. Canada and the US specify a maximum absorption rate of $9 \%$ with similar sample preparation procedures. The UK, Australia and New Zealand specify a maximum of $6 \%$. The requirements for drying and wetting samples in Australia and New Zealand are comparable to that in Canada and the US. However, in the $\mathrm{UK}$, the drying sample process requires that the mass difference is less than $0.1 \%$ in $24 \mathrm{~h}$ instead of 4 or $6 \mathrm{~h}$. The wet sample immerse temperature is $20^{\circ} \mathrm{C}$ compared to over $100{ }^{\circ} \mathrm{C}$, but the acceptance criteria is limited to mass difference of less than $0.1 \%$ in $24 \mathrm{~h}$. The UK appears to have more stringent requirements in measuring the absorption rate compared to that in the other study areas. The concrete absorption test was not found in the Chinese standards.

Table 13. Absorption test limits and requirements.

\begin{tabular}{ccccc}
\hline Study Area & Limit & Dry Sample & $\begin{array}{c}\text { Wet Sample Immerse } \\
\text { Temperature }\end{array}$ & $\begin{array}{c}\text { Wet Sample Immerse } \\
\text { Duration }\end{array}$ \\
\hline US & $9 \%$ & Mass Diff $<0.1 \%$ in $6 \mathrm{~h}$ & $105-115^{\circ} \mathrm{C}$ & $5 \mathrm{hr}$ \\
Canada & $9 \%$ & Mass Diff $<0.1 \%$ in $6 \mathrm{~h}$ & $105-115^{\circ} \mathrm{C}$ & $5 \mathrm{hr}$ \\
UK & $6 \%$ & Mass Diff $<0.1 \%$ in $24 \mathrm{~h}$ & $20 \pm 3{ }^{\circ} \mathrm{C}$ & Mass diff $<0.1 \%$ in $24 \mathrm{~h}$ \\
$\begin{array}{c}\text { Australia/New } \\
\text { Zealand }\end{array}$ & $6 \%$ & Mass Diff $<0.1 \%$ or $<0.5 \mathrm{~g}$ in $4 \mathrm{~h}$ & $100{ }^{\circ} \mathrm{C}$ & $5 \mathrm{~h}$ \\
China & Not specified & Not specified & Not specified & Not specified \\
\hline
\end{tabular}




\subsection{Crack Width}

Crack limits in pipe standards include definitions of crack width and length and are often specified in all study areas to assess structural performance. The limit is specified in the load test to determine the design crack load and thus the classification of the pipe. Hairline cracks, however, occur much earlier than the design crack width, but are not measured or recorded. Cracks provide a path for moisture and harmful ions to ingress. If a crack extends to the reinforcing steel, the pipe becomes susceptible to corrosion. Crack allowance under the load tests in Canada, US and UK are specified as 0.3-mm. Australia and New Zealand allow for a crack of up to $0.25 \mathrm{~mm}$ for concrete cover exceeding 20-mm, while China limits the crack to 0.2-mm. The crack limit without load from Australia and New Zealand is set at $0.1-\mathrm{mm}, 0.15-\mathrm{mm}$ and $0.2-\mathrm{mm}$ for concrete cover less than $10-\mathrm{mm}$, in between 10 and 20-mm, and larger than 20-mm, respectively, which is $0.05 \mathrm{~mm}$ narrower than that when the load is applied. A $0.15-\mathrm{mm}$ crack is permitted in the UK without loading. China specifies $0.05-\mathrm{mm}$ crack width without loading, which is presumably a definition of a hairline crack. If the length of the crack is less than $300-\mathrm{mm}$, then it is generally defined as acceptable. In Canada and the US, there are no specified crack limits without loading.

\subsection{Concrete Cover}

The concrete cover provides a barrier against carbonation and the penetration of chloride and sulfate ions. High early strength cement and high sulfate resistant cement are usually used in RCP products to increase productivity and enhance durability. Table 14 compares the minimum concrete cover specification in relationship to durability among all study areas. For 1200-mm RCP with 125-mm wall thickness, Canada and the US require 13-mm minimum cover, Australia and New Zealand require 10-mm and 25-mm minimum cover for normal or aggressive exposure environments, respectively, the UK requires 15-mm and China requires 20-mm minimum cover. Canada and the US require the least protection from the concrete cover. As mentioned in Section 2.3, concrete cover inspections are mandatory except in Canada where it is an option based on the owner's requirements.

Table 14. Comparison of minimum concrete cover requirements.

\begin{tabular}{|c|c|c|c|c|}
\hline $\begin{array}{l}\text { Minimum Concrete } \\
\text { Cover (mm) }\end{array}$ & Canada/US & Australia/New Zealand & China & UK \\
\hline 6 & - & $\begin{array}{l}\text { Wall } \leq 25 \mathrm{~mm} \text {, normal } \\
\text { exposure, dry cast }\end{array}$ & - & - \\
\hline 8 & - & $\begin{array}{l}25 \mathrm{~mm}<\text { Wall } \leq 35 \mathrm{~mm} \text {, } \\
\text { normal exposure, dry cast }\end{array}$ & - & - \\
\hline 10 & - & $\begin{array}{l}\text { Wall }>35 \mathrm{~mm} \text {, normal } \\
\text { exposure, dry cast }\end{array}$ & Wall $\leq 40 \mathrm{~mm}$ & - \\
\hline 13 & $\begin{array}{l}\text { All wall } \\
\text { thickness }\end{array}$ & - & - & - \\
\hline 15 & - & - & $\begin{array}{c}40 \mathrm{~mm}<\text { Wall } \\
\leq 100 \mathrm{~mm}\end{array}$ & $\begin{array}{c}\text { All wall thickness } \\
\text { (not defined as minimum) }\end{array}$ \\
\hline 20 & - & - & Wall > $100 \mathrm{~mm}$ & - \\
\hline 25 & - & $\begin{array}{l}\text { Wall }>35 \mathrm{~mm} \text {, aggressive } \\
\text { exposure, dry cast }\end{array}$ & - & - \\
\hline 35 & - & $\begin{array}{c}\text { Wall }>35 \mathrm{~mm} \text {, aggressive } \\
\text { exposure, wet cast }\end{array}$ & - & - \\
\hline
\end{tabular}




\section{Discussion and Recommendations}

\subsection{Concrete Cover and Crack Limit}

The thickness of the concrete cover impacts the structural performance and durability of concrete pipe. The placement of the reinforcing steel cage directly affects the flexural strength and crack load, and thus shall be measured and controlled and be part of the acceptance criteria.

Crack limits are defined in standards of all study areas. The load class is defined by the crack limit but the limit is not related to the durability requirements. In the area where RCP is subjected to saline storm-water, appearance of crack and the crack growth can be expedited [39]. When the crack limit is reached, the crack would have extended to the reinforcing steel, which could create a channel for corrosive substances. Hairline cracks occur at a much earlier loading stage. In all study areas, hairline crack is not clearly defined as part of testing, but it is implied that visible cracks smaller than the crack limit are permitted in the pipe. It is assumed that hairline cracks pose no structural concern and will heal after the pipe is put in service owing to the formation of calcium carbonate, which is known as autogenous healing [40]. Yet, significant autogenous healing was not observed in crack widths between $0.5 \mathrm{~mm}$ (0.02 inch) and $3 \mathrm{~mm}$ (0.1 inch). In a report by Busba et al. [41], crack width guideline was provided based on the aggressiveness of the chloride ions environment because the RCP design life will be impacted by the crack width. The standards from the study areas mostly specify a 0.3-mm crack width limit. China, Australia and New Zealand specify as small as a 0.2-mm crack width limit. The pipe crack width limitation in the current standards only relate to structural and hydrostatic criteria, but do not exhibit any rational consideration of durability.

\subsection{Load Test}

The US is the only country surveyed whose standards prescribe steel design without having the load test as a mandatory validation criterion. Load testing is required for classes and sizes not listed in the standard. Standards from the other countries in terms of structural strength are performance based. Canadian standards specify steel requirements, but the pipe is considered acceptable if the manufacturer can demonstrate its capacity through the load test. Both the US and Canada rely on the inspector to observe cracks during the load test. The inspector must capture the moment when the crack limit is reached using a crack gauge. Most of the time, the loading process is continuous at a pre-determined rate, often with only one person assigned to observe the crack. The design crack may occur at the invert or obvert of the pipe from either ends of the specimen, or at the outside of the pipe spring-line. In large diameter pipes, depending on the reinforcing steel configuration, the $0.3-\mathrm{mm}$ crack may be governed by radial tension or shear capacity. It will be very difficult for a single person to determine the location of the first crack that reaches the limit width and the corresponding load value. In many cases, the process relies on inspector experience to observe the crack before physically measuring it. The time required to call an actual design load may sometimes span over $10 \mathrm{kN}$ of load, which can make a difference between a pass or fail decision. In the UK, when the design crack load is reached, the load is held for 3 to $5 \mathrm{~min}$ for examination of the crack. This period allows the inspector to carefully detect the crack and decide. The test procedure in the Chinese standard requires further incremental step loading. The test is required to reach $80 \%$ of the expected crack load followed by incremental loading and pausing. Each increment requires a one to three min hold period for crack examination. A similar approach is taken to determine the ultimate load. At each hold period, the inspector is allowed the time to capture and measure the crack, and use judgement. If the decision is made during the load increment, the final recorded strength is reported back to the previous load increment. This will eliminate bias, yet it is rather a time-consuming process. In Australia and New Zealand, the load test also requires measuring the crack after the load is removed. This is to ensure that the load applied is still in the elastic zone. This could avoid inexperienced inspector overestimating the design crack. 
Considering the discussion above, it is recommended that the load test be conducted with a pause at the design load for crack inspection and load removal, before the ultimate load test is conducted. In addition, to eliminate human interpretation of the crack load, other instrumentation may be introduced such as linear variable differential transducer (LVDT) to determine the crack load by studying the load-deformation curve of the pipe.

\subsection{Hydrostatic Performance Test}

Internal hydrostatic pressure is measured for pipes up to a certain size as a quality control requirement in all study areas. External pressure test, such as ASTM C1103, is offered only as an option to the owner and may not provide cost-effective measures. Gravity sewers in general create an open channel flow inside the pipeline. Unless the pipe is being used as a siphon pipe or there is unplanned blockage of the pipe, the internal pressure does not exceed the depth of the fluid inside the pipe. In deep installations where the sustained ground water level is above the pipe obvert, the external hydrostatic pressure poses a risk of infiltration. The current hydrostatic test does not simulate the actual external pressure. The test only lasts for $10 \mathrm{~min}$ and does not prove performance under sustained pressure. Under current quality programs in the US and Canada, internal hydrostatic tests are not required for larger pipe size due to the difficulty in sealing the pipe. In addition, whether the gasket functions both ways for infiltration and exfiltration requires dedicated investigation. The test does not define the working pressure and ultimate pressure; hence, the pipe cannot be pressure rated. The owner of the pipeline will rely on the field test to evaluate water-tightness. In Australia and New Zealand, there is an option to specify the required pressure rating of the RCP. Consequently, when the external pressure is a concern, the designer may select the concrete pressure pipe. The actual issue occurs when the hydrostatic test is misinterpreted by the specifier and the designer. RCP has been specified in situations where the ground water level is 10-m above the pipe, provided that the pipe is tested to $105 \mathrm{kPa}$. It is thus recommended that concrete pipe standards emphasize an infiltration limit or provide a method to test the infiltration capacity. The hydrostatic performance under a defined joint gap shall also be evaluated. This can potentially quantify the installation quality.

\subsection{Durability}

The simple absorption test is the only test specified in all examined standards. The test is considered as a quality evaluation, yet it is not a reliable parameter for estimating of the concrete pipe durability. The test provides a rough estimation of the pore volume, but gives no indication of the real concrete permeability [42]. No effective measure has yet been put in place to deal with microbiologically induced concrete corrosion (MICC), which is one of the major issues in concrete pipe durability. In terms of concrete pipe durability, all examined standards in the various study areas lag current concrete design codes, such as CSA A23.1 and CSA A23.4. The design guideline was published by the US Environmental Protection Agency as early as 1974 [43] and many municipal standards to prescribe the size, slope and turbulence control for the sole purpose of minimizing hydrogen sulfide and MICC. However, three is no provisions in existing concrete pipe standards to address the threat of MICC.

It is recommended that further development of the absorption test be undertaken. In addition, consideration of the concrete pipe exposure class is recommended. Additional tests for evaluating chloride ions penetration, sulfate attack, MICC as well as minimum cover requirements should be considered in a versatile concrete pipe performance-based standard. This would allow further developments of the RCP technology, including concrete mixtures with less permeability, alternative cementitious materials, and the use of plastic liners.

\section{Conclusions}

Standard provisions for precast concrete pipe around the world have generally been disconnected. For example, Canada has the most stringent hydrostatic performance. China has the tightest geometric tolerance in size and wall thickness and requires more effort in examination of cracks during the load 
test, but does not require hydrostatic joint performance. None of the specifications give consideration to infiltration resistance and MICC exposure evaluation. Nevertheless, there has been little effort to critically analyze the international experience gained in this field, to compare performance criteria and come up with best international practice guidelines. In the present study, a sustained effort was made to critically review current RCP standards from Canada, the US, the UK, Australia, New Zealand, and China so as to reveal strengths and weaknesses that need improvements upon the current state-of-the-art. This effort has exposed various knowledge gaps along with gaps between standards and the end-user expectations in terms of hydrostatic performance against infiltration, durability to hydrogen sulfide attack of the RCP, etc. Recommendations emanating from this critical analysis include the necessity to review and update concrete pipe standards in order to capture modern developments in concrete technology, advances in standard concrete codes and test methods, and to tailor performance-based guidelines that can better capture the pipe structural, hydrostatic and durability performance. These guidelines will set a new platform for technological advancement in $\mathrm{RCP}$. Such an effort is particularly needed to enhance the RCP competitiveness considering the current market reality and the advent of many contenders for concrete pipe replacement using various flexible material formulations.

Author Contributions: The initial draft of this review article was developed by S.W. under the supervision of M.L.N. The final version is the product of collaborative work including input from both authors.

Funding: This research received no funding. Funding for subsequent phases of this research is expected from Con Cast Pipe, Puslinch, ON, Canada and the Natural Science and Engineering Research Council of Canada.

Acknowledgments: The authors acknowledge Con Cast Pipe, Puslinch, ON, Canada for providing information related to their products and industry practice.

Conflicts of Interest: The authors have no conflict of interest to declare.

\section{References}

1. Ontario Concrete Pipe Association (OCPA). Concrete Pipe Design Manual; OCPA: Kitchener, ON, Canada.

2. Schladweiler, J.C. The History of Sanitary Sewer. 2017. Available online: http:/ /www.sewerhistory.org/ (accessed on 14 June 2018).

3. Marston, A.; Anderson, A.O. The Theory of Loads on Pipes in Ditches and Test of Cement and Clay Drain Tile and Sewer Pipe; Iowa State College of Agriculture and Mechanic Arts: Ames, IA, USA, 1931.

4. Orlander, H.C. Stress Analysis of Concrete Pipe; Engineering Monograph No. 6; US Bureau of Reclamation: Washington, DC, USA, 1950.

5. Spangler, M. Soil Engineering; International Textbook Company: Scranton, PA, USA, 1960.

6. Heger, F. Structural Behaviour of Circular Reinforced Concrete Pipe-Development of Theory. J. Proc. 1963, 60, 1567-1614.

7. Heger, F.; Gillespie, J. Design of Circular Concrete Pipe Reinforced with Welded Deformed Wire Fabric; Transportation Research Board: Washington, DC, USA, 1967.

8. American Society of Civil Engineers (ASCE). Standard Practice for Direct Design of Buried Precast Concrete Pipe Using Standard Installation; ASCE15; ASCE: Reston, VA, USA, 1993.

9. American Association of State Highway and Transportation Officials (AASHTO). LRFD Bridge Design Specification; AASHTO: Washington, DC, USA, 2014.

10. CSA Group. Canadian Highway Bridge Design Code; CSA S6; CSA Group: Mississauga, ON, Canada, 2014.

11. British Standards Institution (BSI). Concrete Pipes and Fittings, Unreinforced, Steel Fibre and Reinforced; BS EN 1916:2002; BSI: London, UK, 2002.

12. ASTM International. Standard Specification for Steel Fiber Reinforced Concrete Culvert, Storm Drain, and Sewer Pipe; ASTM C1765; ASTM International: West Conshohocken, PA, USA, 2013.

13. ASTM International. Standard Specification for Synthetic Fiber Reinforced Concrete Culvert, Storm Drain, and Sewer Pipe; ASTM C1818: ASTM International: West Conshohocken, PA, USA, 2015.

14. Mohamed, N.; Soliman, A.M.; Nehdi, M.L. Utilization of steel fibres in precast concrete pipes. In Proceedings of the TAC 2012. Tunnel and Underground Space: Sustainability and Innovations, Montreal, QC, Canada, 17 October 2012; (TAC Paper 158). Transportation Association of Canada: Ottawa, ON, Canada, 2012. 
15. Mohamed, N.; Soliman, A.M.; Nehdi, M.L. Full-scale pipes using dry-cast steel fibre-reinforced concrete. Constr. Build. Mater. 2012, 72, 411-422. [CrossRef]

16. Mohamed, N.; Soliman, A.M.; Nehdi, M.L. Mechanical performance of full-scale precast steel fibre-reinforced concrete pipes. Eng. Struct. 2012, 84, 287-299. [CrossRef]

17. Mohamed, N.; Nehdi, M.L. Rational finite element assisted design of precast steel fibre-reinforced concrete pipes. Eng. Struct. 2012, 124, 196-206. [CrossRef]

18. Lester, H.G. Corrugated Polyethylene Pipe Design Manual \& Installation Guide; Plastic Pipe Institute: Irving, TX, USA, 2017.

19. Curran, S.D. Fiberglass Pipe Past, Present and Future; Fiber Glass Tank and Pipe Institute: Houston, TX, USA, 2013.

20. Walker, R. The Early History of PVC Pipe.1990. Available online: https://theplumber.com/early-history-ofpvc-pipe/ (accessed on 21 June 2018).

21. Rinker Materials. Corrugated Steel Pipe. 1994. Available online: https://www.google. $\mathrm{com} /$ url? sa=t\&rct=j\&q=\&esrc=s\&source=web\&cd=2\&cad=rja\&uact=8\&ved=0ahUKEwi7o6-

3yubbAhXVA4gKHXtJCGIQFggqMAE\&url=https\%3A\%2F\%2Fwww.rinkerpipe.com\%2FTechnicalInfo\% 2Ffiles\%2FInfoBriefs\%2FIS304CorrugatedSteelPipe.pdf\&usg=AOvVaw2tKXPVnfeH7LlycUpm4-cM (accessed on 21 June 2018).

22. Ministry of Transportation Ontario. MTO Gravity Pipe Design Guideline; Ministry of Transportation Ontario: St. Catharines, ON, Canada, 2007.

23. Pratt, C.; Yang, H.; Hodkiewicz, M. Factors Influencing Pipe Failures in the West Australia Environment. 2011. Available online: https://ceed.wa.edu.au/wp-content/uploads/2017/02/Christopher.Pratt_pdf (accessed on 21 June 2018).

24. Parker, C.D. The Corrosion of Concrete. The Sewage Branch of the Melbourne and Metropolitan Board of Works. Aust. J. Exp. Biol. Med. Sci. 1945, 23, 81-90. [CrossRef]

25. Wu, L.; Hu, C.; Liu, W. The sustainability of Concrete in Sewer Tunnel-A Narrative Review of Acid Corrosion in the City of Edmonton Canada. Sustainability 2018, 10, 517. [CrossRef]

26. Vollertsen, J.; Nielsen, A.H.; Jensen, H.S.; Rudelle, E.A.; Hvitved-Jacobsen, T. Modeling the Corrosion of Concrete Sewer. In Proceedings of the 12th International Conference on Urban Drainage, Porto Alegre, Brazil, 11-16 September 2011.

27. Sulikowski, J.; Kozubal, J. The Durability of a Concrete Sewer Pipeline Under Deterioration by Sulphate and Chloride Corrosion. Procedia Eng. 2016, 153, 698-705. [CrossRef]

28. Bielefeldt, A.; Gutierrez-Padilla, M.G.; Ovtchinnikov, S.; Silverstein, J.; Hernandez, M. Backterial Kinetics of Sulfur Oxidizing Bacteria and Their Biodeterioration Rates of Concrete Sewer Pipe Samples. J. Environ. Eng. 2017, 136, 731-738. [CrossRef]

29. Population Reference Bureau. 2013 World Population Data Sheet; Population Reference Bureau: Washington, DC, USA, 2013.

30. Australian Standard. Precast Concrete Pipes (Pressure and Non-Pressure); AS/NZS 4058; Environmental Health Directorate: East Perth, Australia, 2007.

31. Carleton, E.; Hiner, S.; Kurdziel, J. The History and Application of the Three-Edge Bearing Test for Concrete Pipe. In Concrete Pipe and Box Culverts; Meyerand, J.J., Beakley, J., Eds.; ASTM STP1601; ASTM International: West Conshohocken, PA, USA, 2017; pp. 18-27.

32. CSA Group. Standards for Concrete Pipe and Manhole Sections; CSA A257; CSA Group: Mississauga, ON, Canada, 2014.

33. ASTM International. Standard Test Methods for Concrete Pipe, Manhole Sections, or Tile; ASTM C497; ASTM International: West Conshohocken, PA, USA, 2015.

34. Test Methods of Concrete and Reinforced Concrete Drainage and Sewer Pipe; GB/T 16752; Standardization Administration of the People's Republic of China: Beijing, China, 2006.

35. ASTM International. Standard Specification for Reinforced Concrete Culvert, Storm Drain, and Sewer Pipe; ASTM C76; ASTM International: West Conshohocken, PA, USA, 2016.

36. ASTM International. Standard Specification for Joints for Concrete Pipe and Manholes, Using Rubber Gasket; ASTM C443; ASTM International: West Conshohocken, PA, USA, 2012.

37. ASTM International. Standard Specification for Joints for Concrete Pipe, Manholes, and Precast Box Sections Using Preformed Flexible Joint Sealants; ASTM C990; ASTM International: West Conshohocken, PA, USA, 2009.

38. ASTM International. Standard Specification for Joints for Concrete Gravity Flow Sewer Pipe, Using Rubber Gaskets; ASTM C1628; ASTM International: West Conshohocken, PA, USA, 2017.

39. Marr, J. A Research Plan and Report on Factors Affecting Culvert Pipe Service Life in Minnesota; Minnesota Department of Transportation: Saint Paul, MN, USA, 2012. 
40. American Concrete Pipe Association. Cracks in Installed Reinforced Concrete Pipe; American Concrete Pipe Association: Irving, TX, USA, 2007.

41. Busba, E.R.; Sagues, A.A.; Mullins, G. Reinforced Concrete Pipe Cracks-Acceptance Criteria; University of South Florida: Tampa, FL, USA, 2009.

42. De Schutter, G.; Audenaert, K. Evaluation of water absorption of concrete as a measure for resistance against carbonation and chloride migration. Mater. Struct. 2004, 37, 591-596. [CrossRef]

43. Environmental Protection Agency (EPA). Process Design Manual for Sulfide Control in Sanitary Sewerage System; Environmental Protection Agency: Washington, DC, USA, 1974.

2018 by the authors. Licensee MDPI, Basel, Switzerland. This article is an open access article distributed under the terms and conditions of the Creative Commons Attribution (CC BY) license (http://creativecommons.org/licenses/by/4.0/). 